\title{
NASKAH AKADEMIK \\ RANCANGAN PERATURAN DAERAH TENTANG \\ PEDOMAN TEKNIS PERATURAN DESA
}




\section{KATA PENGANTAR}

Puji dan syukur kita panjatkan kehadirat Allah SWT atas rahmat dan karunia-Nya serta taufiq dan hidayah-Nya, sehingga naskah akademik tentang pedoman teknis penyusunan peraturan desa dapat kami selesaikan.

Gagasan untuk menyusun naskah akademik ini muncul dari harapan dan keinginan Pemerintah Daerah .................. untuk menertibkan masyarakat guna terwujudnya suasana yang kondusif menuju tercapainya kesejahteraan dan ketentraman hidup bermasyarakat.

Dengan tersususnya naskah akademik, diharapkan dapat dijadikan sebagai acuan bagi pengambil keputusan Pemerintah Daerah dalam upaya mengajak dan melakukan pembinaan pada individu, maupun kelompok masyarakat.

Kami menyadari sepenuhnya, walaupun telah bekerja keras melakukan yang terbaik dalam penyusunan naskah akademik ini, namun tentu saja masih terdapat kelemahan dan kekurangan bahkan mungkin ada kesalahan dalam penyajian tulisan ini. Untuk itu, koreksi dan masukan sangat kami harapkan, guna penyempurnaan naskah akademik ini.

Akhirnya dalam kesempatan ini, kami menyampaikan ucapan terima kasih kepada berbagai pihak yang telah turut serta membantu dalam memberikan kontribusi pemikiran, perhatian dan bantuannya terhadap penyelesaian serta penyusunan naskah akademik untuk Peraturan Daerah Pedoman Teknis Penyusunan Peraturan Desa, semoga bermanfaat.

, Februari 2018

TIM PENYUSUN 


\section{DAFTAR ISI}

Halaman Judul

Kata Pengantar

Daftar Isi

\section{BAB I PENDAHULUAN}
A. Latar Belakang 1

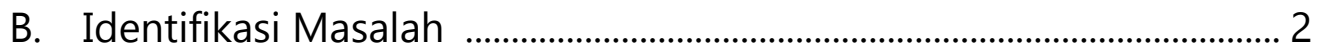

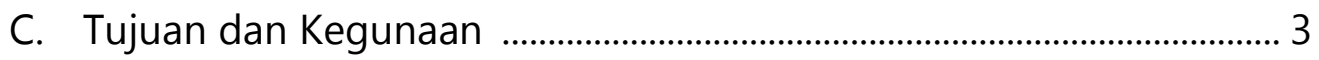
D. Metode Penelitian ..................................................................................... 4

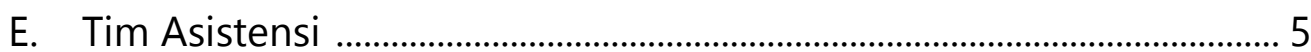

\section{BAB II KAJIAN TEORITIK DAN PRATEK EMPIRIK}
A. Kajian Teoritik 6
B. Kajian Asas/Prinsip 9
C. Praktek Pedoman Organisasi dan Tata Kerja Pemerintah Desa 12
D. Dampak Pembatasan 13
E. Dampak Pembebanan Keuangan Daerah .............................................. 14
F. Dampak Positif ................................................................................................ 15
G. Dampak Negatif ............................................................................................ 15

\section{BAB III ANALISIS DAN EFALUASI PERATURAN PERUNDANG-}

UNDANGAN.

BAB IV LANDASAN FILOSOFIS, YURIDIS, DAN SOSIOLOGIS
A. Landasan Filosofis 30
B. Landasan Yuridis
C. Landasan Sosiologis

BAB V JANGKAUAN ARAH PENGATURAN, DAN RUANG LINGKUP MATERI MUATAN UNDANG-UNDANG
A. Sasaran .43
B. Jangkaun dan Arah Pengaturan . .43
C. Ruang Lingkup Muatan Materi Undang-Undang .43

\section{BAB VI PENUTUP}
A. Kesimpulan .48
B. Rekomendasi 


\section{BAB I \\ PENDAHULUAN}

\section{A. Latar Belakang}

Reformasi penyelenggaraan pemerintahan desa pada hakekatnya adalah suatu proses pembalikan paradigma politik, dimana proses demokratisasi yang selama Orde Baru berproses dari atas, kemudian dibalik melalui proses yang berangkat dari desa. Dalam paradigma baru tersebut, desa merupakan kesatuan hukum yang otonom dan memiliki hak dan wewenang untuk mengatur rumah tangga sendiri ${ }^{1}$.

Efektivitas dan efisiensi pembangunan membutuhkan terpenuhinya prasyarat berupa tata pemerintahan yang baik dan bersih (good and clean government). Aspek-aspek penyelenggaraan pemerintahan mengeliminasi praktek-praktek tidak sehat dan merupakan mekanisme kontrol dalam penyelenggaraan pemerintahan. Sehubungan dengan hal tersebut, Pemerintah Desa dalam menyelenggarakan pemerintahan di desa juga harus menerapkan prinsip-prinsip pemerintahan yang baik. Guna mendukung pelaksanaannya maka perlu adanya pengaturan yang jelas sebagai pedoman dan guna mewujudkan kepastian hukum dalam penyelenggaraan pemerintahan di desa.

Meskipun masyarakat desa lebih bersifat homogen namun sebagaimana adanya pola hubungan antar individu, maupun antar individu dengan Pemerintah Desa, antara lembaga yang ada di desa dan semua komponen yang berkepentingan di desa, maka perlu disepakati norma-norma yang secara positif mengikat dan diakui serta terlembaga dalam bentuk-bentuk peraturan perundangan ${ }^{2}$.

Ali fauzan, Implementasi Peraturan Pemeirntah Nomor 72 Tahun 2005 tentang Desa Terkait dengan Peran Badan Permusyawaratan Desa dalam Penyusunan dan Penetapan Peraturan Desa di Kecamatan Wanasari Kabupaten Brebes, Disertasi Program Pascasarjana Undip, 2010.

2 Bagian Pemerintahan Desa Dan Kelurahan Sekretariat Daerah Kabupaten Karanganyar Tahun 2014 
Sesuai Undang-Undang Nomor 6 Tahun 2014 institusi yang memikul tanggung jawab menyelenggarakan kewenangan desa adalah Pemerintah Desa beserta aparatnya, Badan Permusyawaratan Desa yang didukung oleh masyarakat setempat. Penyelenggara kewenangan desa ini diberi tugas dan fungsi masingmasing akan tetapi tugas dan fungsi itu dijalankan secara bersinergi agar supaya terwujud masyarakat desa yang sejahtera berkeadilan. Salah satu tugas institusi yang harus didukung oleh masyarakat desa adalah menyusun produk hukum desa khususnya perdes tentang anggaran pembangunan desa dan kerjasama antar desa sebagai acuan pelaksanaan pembangunan desa. Perdes yang rancangannya harus diajukan oleh Kepala Desa beserta aparatnya atau dapat diajukan pula oleh BPD harus mendapat persetujuan BPD wajib dikonsultasikan kepada warga masyarakat.

Dalam rangka menjawab berbagai persoalan diatas, salah satu strategi yang sangat perlu dan mendesak adalah perlu segera menyusun sebuah rancangan Peraturan Daerah Tentang Teknis Penyusunan Peraturan Desa untuk menggantikan Peraturan Daerah sebelumnya ataupun membuat peraturan baru dari sebelumnya belum ada.

\section{B. Identifikasi Masalah}

Perubahan tatanan hukum tentang desa serta penataan pedoman organisasi dan tata kerja pemerintah desa yang diikuti dengan perubahan sosial yang terjadi pada masyarakat di ................ merupakan kondisi masyarakat yang mengalami berbagai pergeseran tatanan kehidupan sosial politik, konsekuensi yang harus dihadapi yaitu terjadinya perubahan pola pikir, pola tindak sehingga kondisi masyarakat menjadi semakin rentan terhadap konflik, maka yang perlu diidentifikasi dalam kajian ini adalah bagaimana upaya Pemerintah Daerah untuk mewujudkan 
yang sejahtera melalui pengaturan hukum

terhadap Teknis Penyusunan Peraturan Desa.

- Apa kriteria untuk Teknis Penyusunan Peraturan Desa yang dibatasi dan terhadap siapa pembatasan tersebut diberlakukan/diterapkan?

- Permasalahan-permasalahan apa yang dihadapi dalam kehidupan berbangsa, bernegara dan bermasyarakat, sehingga diperlukan adanya pengaturan mengenai Teknis Penyusunan Peraturan Desa?

- Apa argumentasi filosofis, sosiologis dan yuridis mengenai perlunya pengaturan Teknis Penyusunan Peraturan Desa?

- Apa dampak sosial, ekonomi, dan budaya yang harus diperhatikan apabila ketentuan mengenai Teknis Penyusunan Peraturan Desa?

- Apa sasaran, arah dan jangkauan serta ruang lingkup pengaturan Teknis Penyusunan Peraturan Desa?

- $\quad$ Bagaimanakah sanksi terhadap setiap orang yang melanggar ketentuan Teknis Penyusunan Peraturan Desa?

\section{Tujuan dan Kegunaan}

\section{Tujuan Penyusunan Naskah Akademik meliputi :}

1. Merumuskan kriteria Teknis Penyusunan Peraturan Desa yang harus dibatasi dan terhadap siapa pembatasan ini diterapkan.

2. Menggambarkan permasalahan-permasalahan yang dihadapi dalam kehidupan berbangsa, bernegara dan bermasyarakat, yang penyelesaiannya memerlukan adanya pengaturan mengenai Teknis Penyusunan Peraturan Desa.

3. Menguraikan argumentasi filosofis, sosiologis dan yuridis mengenai perlunya pengaturan Teknis Penyusunan Peraturan Desa. 
4. Menguraikan dampak sosial, ekonomi, dan budaya yang harus diperhatikan apabila ketentuan mengenai Teknis Penyusunan Peraturan Desa.

5. Mengelaborasi sasaran, arah dan jangkauan serta ruang lingkup pengaturan Teknis Penyusunan Peraturan Desa.

6. Menguraikan sanksi terhadap setiap orang yang melanggar ketentuan Teknis Penyusunan Peraturan Desa.

7. Menentukan instansi yang memiliki kewenangan untuk melakukan pengawasan Teknis Penyusunan Peraturan Desa.

Kegunaan Penyusunan Naskah Akademik

Penyusunan naskah akademik ini berguna sebagai bahan acuan dalam pengambilan kebijakan masyarakat tentang Teknis Penyusunan Peraturan Desa di ................ sebagai bahan pendukung proses harmonisasi serta sebagai persyaratan dalam pengajuan Prioritas Tahunan Program Legislasi Daerah (Prolegda).

\section{Metode Penelitian}

Metode pendekatan yang digunakan dalam penyusunan naskah akademik ini adalah metode yuridis normatif atau penelitian hukum kepustakaan. Sejalan dengan itu, maka sumber penelitian hukum berupa bahan-bahan hukum (primer, sekunder dan tersier) seperti peraturan dasar, peraturan perundang-undangan, tulisan-tulisan, literatur, serta hasil penelitian yang akan dipergunakan.

Bahan-bahan hukum primer terdiri dari perundang-undangan, catatan-catatan resmi atau risalah dalam pembuatan Perundangundangan dan putusan-putusan hakim. Sedangkan bahan-bahan sekunder berupa semua publikasi tentang hukum yang bukan merupakan dokumen-dokumen resmi. Publikasi tentang hukum meliputi buku-buku teks, kamus-kamus hukum, jurnal-jurnal 
hukum, dan komentar komentar atas putusan pengadilan (bahanbahan tersier) ${ }^{3}$.

Berdasarkan metode tersebut, data dan informasi yang diperoleh akan disusun secara deskriptif dan sistimatis untuk memudahkan bagi pengambilan kebijakan dan membantu perumusan norma oleh perancang Perundang-undangan (legal drafter). Penyusunan naskah akademik tentang Teknis Penyusunan Peraturan Desa ini juga didukung oleh studi perbandingan dengan mengambil bahan hukum sekunder yang tidak hanya dari .................., tetapi juga dari daerah lain.

Dalam memperkaya substansi, maka naskah akademik tentang Teknis Penyusunan Peraturan Desa akan menggunakan analisis kualitatif dan kuantitatif dari berbagai narasumber yang terkait dengan penyelenggaraan.

E.

${ }^{3}$ Peter Mahmud Marzuki, Penelitian Hukum, Penerbit Kencana, Tahun 2007, hlm. 141 
KAJIAN TEORITIK DAN PRAKTEK EMPIRIK

\section{A. Kajian Teoritik}

Teori Demokrasi

Kata demokrasi berasal dari dua kata, yaitu demos yang berarti rakyat, dan kratos atau cratein yang berarti pemerintahan, sehingga dapat diartikan pemerintahan rakyat, atau pemerintahan dari rakyat, oleh rakyat dan untuk rakyat. Suatu Negara demokrasi adalah Negara yang diselenggarakan berdasarkan kehendak dan kemauan rakyat, atau jika ditinjau dari sudut organisasi, ia berarti suatu pengorganisasian Negara yang dilakukan oleh rakyat sendiri atau atas persetujuan rakyat karena kedaulatan ada di tangan rakyat (Kurde, 2005:62). Menurut International Commission of Jurits, sebagaimana dikutip oleh Meriam Budiarjo (Green Mind Community, 2009: 141), dikatakan bahwa demokrasi merupakan suatu bentuk pemerintahan dimana hak untuk membuat keputusan-keputusan politik diselenggarakan oleh warga negara melalui wakil yang dipilih oleh mereka melalui suatu proses pemilihan yang bebas ${ }^{4}$.

Dalam wacana ilmu politik, konsepsi demokrasi seperti ini dikenal dengan demokrasi deliberatif. Dalam model demokrasi deliberatif suatu keputusan politik dikatakan benar jika memenuhi empat prasyarat. Pertama, harus didasarkan pada fakta, bukan hanya didasarkan pada ideologi dan kepentingan. Kedua, didedikasikan bagi kepentingan banyak orang, bukan demi kepentingan perseorangan atau golongan. Ketiga, berorientasi jauh ke depan, bukan demi kepentingan jangka pendek atau politik dagang sapi yang bersifat kompromistis. Keempat, bersifat imparsial. Dengan melibatkan dan mempertimbangkan pendapat semua pihak (minoritas terkecil sekalipun) secara inklusif. Dalam model itu, legitimasi demokrasi tidak

4 http://e-journal.uajy.ac.id/6944/3/MIH202042.pdf 
ditentukan oleh seberapa banyak dukungan atas suatu keputusan, melainkan seberapa luas dan dalam melibatkan proses deliberasi.

Nilai-nilai demokrasi sudah lama dikenal oleh masyarakat Indonesia, demokrasi desa merupakan demokrasi asli dari masyarakat yang belum mengalami perubahan serta menyatu dalam kehidupanya. Desa adalah daerah otonom yang paling tua, karena dia ada sebelum komunitas yang lebih besar bahkan negara lahir. Budaya yang hidup di desa seperti gotong-royong, musyawarah, saling menghargai dan menghormati hakekatnya cerminan dari demokrasi itu sendiri.

Dalam hal ini nampak bahwa sejak dulu demokrasi sudah diterapkan dalam suatu negara di mana ada pihak yang mewakili dan pihak yang terwakili. Sistem yang banyak dianut di negara-negara di dunia karena dianggap paling baik adalah sistem demokrasi. Dengan begitu demokrasi merupakan satu sistem pemerintahan dimana pada prinsipnya semua orang mempunyai hak sama untuk memerintah dan juga untuk di perintah. Demokrasi menghendakai keharusan adanya kebebasan untuk berfikir dan berkeyakinan, kebebasan ilmiah, kebebasan mengeluarkan pendapat, rule of law, dan persamaan di muka hukum.

Perlakuan demokrasi di setiap negara tidak selalu sama, oleh karena demokrasi pada kenyataannya, memang tumbuh bukan diciptakan. Maka setidaknya, negara dikatakan demokratis jika memenuhi syarat sebagaimana dikemukan oleh Bagir Manan:

1. Ada kebebasan untuk membentuk dan menjadi anggota perkumpulan.

2. Ada kebebasan menyatakan pendapat.

3. Ada hak untuk memberikan suara dalam pemungutan suara.

4. Ada kesempatan untuk dipilh atau menduduki berbagai jabatan pemerintahan atau negara.

5. Ada hak bagi para aktivis politik berkampanye untuk meperoleh dukungan atau suara. 
6. Terdapat berbagai sumber informasi.

7. Ada pemilihan yang bebas dan jujur.

8. Semua lembaga yang bertugas merumuskan kebijakan.

Penguasa politik dengan penguatan demokrasi, membuka ruang dialog sekaligus komonikasi di ruang-ruang public (public sphere Habermas) dalam meningkatkan komonikasi yang partisipatoris. Penguasa politik membuka keran dialog, untuk dikoreksi dan dikritik atas setiap kebijakan politik yang diambilnya ${ }^{5}$.

\section{Konsep Teknis Penyusunan Peraturan Desa}

Peraturan Desa ditetapkan oleh kepala desa setelah mendapat persetujuan bersama Badan Perwakilan Desa, yang dibentuk dalam rangka penyelenggaraan otonomi desa. Perdes merupakan penjabaran lebih lanjut dari peraturan perundangundangan yang lebih tinggi dengan memperhatikan ciri khas masing-masing desa. Sehubungan dengan hal tersebut, sebuah Perdes dilarang bertentangan dengan kepentingan umum dan/atau peraturan perundang-undangan yang lebih tinggi. Dalam konsep negara hukum yang demokratis keberadaan peraturan perundang-undangan, termasuk Peraturan Desa dalam pembentukannya harus didasarkan pada beberapa asas.

Menurut Van der Vlies sebagaimana dikutip oleh A. Hamid S. Attamimi membedakan 2 (dua) kategori asas-asas pembentukan peraturan perundang-undangan yang patut (beginselen van behoorlijk rcgelgeving), yaitu asas formal dan asas material. Asas-asas formal meliputi:

1. Asas tujuan jelas (Het beginsel van duideijke doelstellin)

2. Asas lembaga yang tepat (Het beginsel van het juiste orgaan)

5 Damang Averroes Al-Khawarizmi. Http://Www.Negarahukum.Com/Hukum/TeoriDemokrasi.Html 
3. Asas perlunya pengaturan (Het noodzakelijkheid beginsel)

4. Asas dapat dilaksanakan (Het beginsel van uitvoorbaarheid)

5. Asas Konsensus (het beginsel van de consensus)

Asas-asas material meliputi:

1. Asas kejelasan Terminologi dan sistematika (het beginsel van de duiddelijke terminologie en duidelijke systematiek).

2. Asas bahwa peraturan perundang-undangan mudah dikenali (Het beginsel van den kenbaarheid)

3. Asas persamaan (Het rechts gelijkheids beginsel)

4. Asas kepastian hukum (Het rechtszekerheids begin sel)

5. Asas pelaksanaan hukum sesuai dengan keadaan individual (Het beginsel van de individuelerechtsbedeling)

Asas-asas ini lebih bersifat normatif, meskipun bukan norma hukum, karena pertimbangan etik yang masuk ke dalam ranah hukum. Asas-asas pembentukan peraturan perundang-undangan ini penting untuk diterapkan karena dalam era otonomi luas dapat terjadi pembentuk Peraturan Desa membuat suatu peraturan atas dasar intuisi sesaat bukan karena kebutuhan masyarakat. Pada prinsipnya asas pembentukan peraturan perundang-undangan sangat relevan dengan asas umum administrasi publik yang baik (general principles of good administration) ${ }^{6}$.

\section{B. Kajian Asas/Prinsip}

\section{Asas Manfaat}

Suatu Undang-Undang perlu juga memperhatikan prinsip atau asas manfaat. Asas manfaat dalam pembentukan suatu Undangundang mengacu kepada pengertian bahwa Undang-undang tersebut memberikan atau membawa manfaat kepada orang banyak. Prinsip atau asas ini lebih dikenal dengan istilah

6 https://rechtboy.wordpress.com/2008/03/25/pembentukan-peraturan-desa/ 
"greatest good for the greatest number of citizens" yang diperkenalkan oleh Jeremy Bentham ${ }^{7}$.

Pembatasan aktifitas pada rancangan undang-undang pedoman organisasi dan tata pemerintah desa dengan mengarahkan masyarakat pada kegiatan yang merupakan kebermanfaatan dari apa yang akan diatur dalam peraturan daerah mengenai gerakan yang dilakukan secara bersama-sama dengan tujuan untuk mencapai keharmonisan dalam kehidupan.

2. Asas Kepentingan Umum

Asas kepentingan umum merupakan asas yang berdasarkan pada kewenangan negara untuk melindungi dan mengatur masyarakat lebih luas. Dalam hal ini negara dapat menentukan semua keadaan dan peristiwa yang sesuai dengan kepentingan umum. Tujuan asas kepentingan umum adalah untuk mewujudkan ketertiban dan keamanan seluruh masyarakat. Pengaturan yang berkaitan dengan kepentingan umum tidak berkait dengan apa yang diberikan oleh negara.

Asas kepentingan umum adalah suatu asas yang mendahulukan kebutuhan masyarakat umum dibandingkan dengan kebutuhan masyarakat atau golongan tertentu.

Selanjutnya kepentingan umum juga diuraikan lebih lanjut dalam penjelasan Pasal 49 b Undang-undang Nomor 5 Tahun 1986 tentang Peradilan Tata Usaha Negara yang menyatakan bahwa kepentingan umum adalah "kepentingan bangsa dan Negara dan/atau kepentingan masyarakat bersama dan/atau kepentingan pembangunan, sesuai dengan peraturan PerundangUndangan yang berlaku".

Berdasarkan uraian di atas dapat disimpulkan bahwa pengertian kepentingan umum adalah kepentingan yang harus didahulukan

7 Jeremy Bentham, An Introduction to the Principles of Morals and Legislation, Batoche Books: Kitchener, ON Canada, 2000, p. 14. 


\section{।}

dari kepentingan-kepentingan yang lain dengan tetap memperhatikan proporsi pentingnya dan tetap menghormati kepentingan-kepentingan lain.

Seyogyanya kepentingan umum dalam peraturan perundangundangan tetap dirumuskan secara umum atau luas. Kalau dirumuskan secara rinci atau kasuistis dalam peraturan perundang-undangan penerapannya akan kaku, karena hakim lalu terikat pada rumusan Undang-undang. Rumusan umum oleh pembentuk Undang-undang akan lebih luwes/fleksibel karena penerapan atau penafsirannya oleh hakim berdasarkan kebebasannya, dapat secara kasuistis disesuaikan dengan perkembangan masyarakat dan keadaan.

3. Asas Hukum sebagai Alat Rekayasa Sosial

Pada asas ini dijabarkan peran hukum sebagai "sarana rekayasa sosial" atau sarana untuk menentukan arah pembangunan masyarakat yang dikehendaki agar lebih baik. Hukum sebagai sarana perubahan sosial (law as tool of social engineering) menuju kondisi hukum yang lebih baik ini diungkapkan oleh Roscoe Pound.

Dalam Undang-undang ini, penggunaan asas hukum sebagai alat rekayasa sosial sangat penting sebab pembentukan Undangundang keuangan desa adalah upaya mengubah serta memperbaiki kebiasaan masyarakat dari keterbatasan menjadi lebih fleksibel dan berkesinambungan.

Oleh karena itu, sebelum sebuah kebijakan disampaikan ke ruang publik, perlu sosialisasi yang massal agar informasi yang akurat sampai ke masyarakat dan merekonstruksi kesadaran hukum baru $^{8}$. Peran hukum (peraturan perundang-undangan) sebagai

Joseph Raz, The Concept of A Legal System: An Introduction to the Theory of Legal System, Oxford: Clarendon Press, 1997, p.165. Dalam terminologi Raz, kesadaran hukum dimulai dari sebentuk pengetahuan terlebih dahulu yang menggumpal dalam memori ingatan, sebelum akhirnya mempengaruhi tindakan personal dan bersifat psikologis. 
sarana rekayasa sosial dalam mengubah gaya bermasyarakat dalam melakukan transaksi penting. Adanya gagasan atas perubahan sosial kearah yang lebih baik dengan cara yang benar dan lebih realistis dapat mendorong keinginan masyarakat untuk berpartisipasi dalam misi atas perubahan sosial tersebut ${ }^{9}$.

\section{Praktek Pelaksanaan Pedoman Teknis Penyusunan Peraturan Desa}

1. Telah ada ketentuan sebelumnya

- Pasal 18 Ayat (6) dan Pasal 33 Ayat (1) Undang-undang Dasar 1945

- Undang-Undang Republik Indonesia Nomor 12 Tahun 2011 Tentang Pembentukan Peraturan Perundang-Undangan

- Undang-Undang Republik Indonesia Nomor 6 Tahun 2014 Tentang Desa

- Undang-Undang Republik Indonesia Nomor 23 Tahun 2014 Tentang Pemerintahan Daerah

- Peraturan Pemerintah Republik Indonesia Nomor 43 Tahun 2014 Tentang Peraturan Pelaksanaan Undang-Undang Nomor 6 Tahun 2014 Tentang Desa.

- Peraturan Menteri Dalam Negeri Nomor 111 Tahun 2014 tentang Pedoman Tehnis Penyusunan Peraturan di Desa

2. Pentingnya Sosialisasi peraturan Pedoman Teknis Penyusunan Peraturan Desa

Sasaran sosialisasi peraturan tentang pedoman organisasi dan tata kerja pemerintah desa yakni seluruh masyarakat

9 Jimly Asshiddiqie, Konstitusi Ekonomi, Kompas Januari 2010, Jakarta, hal 16 
yang berdomisili pada wilayah pemerintahan dengan orientasi untuk pemanfaatan struktur

hukum yang terbarukan. Upaya sosialisasi dilaksanakan untuk menghindar kesalahan dalam menafsir maupun mempraktekkan fungsi dan tujuan keuangan desa itu sendiri di tengah-tengah masyarakat. Strategi sosialisasi yang sekiranya dapat dilakukan lewat media tulis, media sosial ataupun tatap muka, maka dengan demikian diharapkan akan terjadi transformasi informasi serta pengetahuan tentang pedoman teknis penyusunan peraturan desa.

\section{Dampak Pembatasan}

- Aspek sosial kemasyarakatan

Pembatasan kesempatan ketika seseorang atau kelompok akan mengembangkan potensi diri pada tingkatan tertentu serta keinginan untuk ikut berperan dan berpartisipasi dalam pembangunan desa mengakibatkan adanya peningkatan atau pertumbuhan usaha untuk mendapatkan legalitas sebagai salah satu bagian dan objektifikasi bahwa yang bersangkutan memiliki kemampuan untuk mengolah organisasi serta menjalankan tata kerja pemerintah desa. Apa yang kemudian menjadi dampak akibat peraturan tersebut merupakan konsekuensi logis sebagai akibat dari pelaksanaan dari peraturan yang telah ditetapkan

- Aspek penegakan hukum

Penegakan hukum dari ketentuan, dalam hal ini penegakan hukum dalam arti sempit, yaitu upaya aparatur penegak hukum untuk menjamin dan memastikan bahwa suatu aturan hukum berjalan sebagaimana seharusnya, memerlukan pula suatu daya paksa guna memastikan bahwa suatu aturan hukum berjalan sebagaimana mestinya 


\section{E. Dampak Pembebanan Keuangan Daerah}

1. Biaya Penyusunan Undang-undang

Biaya penyusunan Undang-undang yang diperlukan adalah sejak dari penyusunan draft awal Undang-undang pedoman organisasi dan tata kerja pemerintah desa di Pemerintah Daerah ................., biaya pembahasan antar lembaga, biaya harmonisasi peraturan perundang-undangan terkait.

2. Biaya Pembahasan Undang-undang

Biaya pembahasan Undang-undang meliputi penggandaan dan penjilidan Naskah Akademik dan Undang-undangnya, biaya pembahasan penyusunan antara pemerintah Daerah ................. dan Dewan Perwakilan Rakyat Daerah

3. Biaya Pencetakan Resmi Naskah Undang-undang

Biaya yang diperlukan meliputi biaya editing, pencetakan naskah resmi dalam lembaran Negara dan tambahan lembaran negara, dan pengirimannya ke instansi resmi dan masyarakat.

4. Biaya Sosialisasi Undang-undang

Pengaturan mengenai pedoman organisasi dan tata kerja pemerintah desa merupakan sesuatu yang baru bagi sebagian besar masyarakat, sehingga untuk memasyarakatkannya diperlukan sosialisasi secara gencar dan berkesinambungan. Sosialisasi yang dilakukan harus melalui berbagai sarana media, baik cetak maupun elektronik.

Sosialisasi dilakukan di seluruh wilayah atau daerah otonom, biaya yang dibutuhkan cukup besar karena harus mampu menjangkau daerah-daerah pada lokasi yang sulit untuk diakses.

5. Kelembagaan

Kelembagaan sebaiknya dengan memberikan kewenangan terhadap lembaga yang sudah ada. Akan tetapi yang diperlukan adalah adanya biaya untuk melakukan koordinasi 
antar lembaga terkait agar jelas peran dan fungsi masingmasing lembaga karena dalam pelaksanaannya peraturan daerah mengenai pedoman organisasi dan tata kerja pemerintah desa akan terkait sejak dari pelaksanaan, pengawasannya dan penegakan hukumnya.

\section{F. Dampak Positif}

Kehadiran Peraturan Daerah tentang pedoman penyusunan peraturan Desa akan berdampak positif bagi pembangunan di Desa. Peraturan Daerah ini akan menjadi pemicu semangat bagi pemerintah Desa untuk membuat beberapa peraturan desa tentang pembangunan desa khususnya bagi pembangunan ekonomi. Lahirnya Peraturan Desa memberikan kepastian hukum bagi pemerintah dan masyarakat desa untuk melakukan kegiatan yang produktif. Keinginan dan kegiatan masyarakat yang bersifat produktif akan lebih bebas bergerak degan adanya peraturan desa yang dibuat oleh Pemerintah Desa.

Dampak positif lain yang dapat timbul adalah adanya kesepahaman tentang prosedur dan tata cara pembentukan Peraturan Desa. Peraturan Daerah ini menjadi payung bersama bagi pemerintah Desa dalam merumuskan Peraturan Desa. Aparat pemerintahan Desa akan mendapatkan wawasan yang lebih luas terkait dengan tata cara lahirnya produk perundang-undangan.

\section{G. Dampak Negatif}

Dampak negatif yang mungkin akan timbul adalah adanya rasa keengganan bagi pemerintahan desa untuk membuat Peraturan Desa. hal ini disebabkan oleh adanya proses birokrasi yang menurut mereka panjang. Peraturan Daerah ini akan membatasi pemerintah desa dalam menyusun Peraturan desa yang selama ini telah mereka buat. Hal ini tentunya akan menjadi tantangan bagi pemerintah Kabupten untuk memberikan pemahaman kepada pemerintahan desa terkait pentingnya pedoman bagi penyusunan sebuah Peraturan. 


\section{BAB III}

ANALISIS DAN EVALUASI PERATURAN PERUNDANG-UNDANGAN

- Pasal 18 Ayat (6) dan Pasal 33 Ayat (1) Undang-undang Dasar 1945.

Kinerja dibidang pembentukan peraturan perundang-undangan dalam 10 tahun terakhir ini memperlihatkan peningkatan baik secara kualitas maupun kuantitas. Hal ini tidak terlepas dari proses penyusunan pembentukan peraturan perundang-undangan yang makin tertib, terarah, dan terukur, meskipun dari segi waktu masih perlu percepatan tanpa mengurangi kualitas suatu peratuan perundang-undangan. Percepatan penyelesaian suatu produk peraturan perundang-undangan perlu didorong terhadap program pembentukan peraturan perundang-undangan untuk merealisasikan program-program startegis pembangunan.

Penyerahan sebagian besar kewenangan pemerintahan kepada pemerintah daerah, telah menempatkan pemerintah daerah sebagai ujung tombak pembangunan nasional, dalam rangka menciptakan kemakmuran rakyat secara adil dan merata. Dalam kaitan ini peran dan dukungan daerah dalam rangka pelaksanaan pembentukan peraturan perundang-undanagan sangat strategis, khususnya dalam membuat peraturan daerah (Perda) dan peraturan daerah lainnya sesuai dengan ketentuan peraturan perundang-undangan.

Perda sebagai jenis peraturan perundang-undangan nasional memiliki landasan konstitusional dan landasan yuridis dengan diaturnya kedudukan Perda dalam Undang-Undang Dasar 1945 Pasal 18 ayat (6) yang menyatakan bahwa pemerintah daerah berhak menetapkan peraturan daerah dan peraturan-peraturan lain untuk melaksanakan otonomi daerah dan tugas pembantuan. Dalam kaitan ini, maka sistem hukum nasional memberikan kewenangan atributif kepada daerah untuk menetapkan Perda dan Peraturan lainnya, dan Perda diharapkan dapat mendukung secara sinergis programprogram Pemerintah di daerah. 
Perda sebagaimana Peraturan perundang-undangan lainnya memiliki fungsi untuk mewujudkan kepastian hukum (rechtszekerheid, legal certainty). Untuk berfungsinya kepastian hukum Peraturan perundang-undanagn harus memenuhi syaratsyarat tertentu antara lain konsisten dalam perumusan dimana dalam peraturan perundang-undangan yang sama harus terpelihara hubungan sistematik antara kaidah-kaidahnya, kebakuan susunan dan bahasa, dan adanya hubungan harmonisasi antara berbagai peraturan perundang-undangan.

Pengharmonisasian peraturan perundang-undangan memiliki urgensi dalam kaitan dengan asas peraturan perundang-undangan yang lebih rendah tidak boleh bertentangan dengan peraturan perundang-undangan yang lebih tinggi, sehingga hal yang mendasar dalam penyusunan rancangan peraturan daerah adalah kesesuaian dan kesinkronannya dengan peraturan perundang-undangan lainnya. 
- Undang-Undang Republik Indonesia Nomor 12 Tahun 2011 Tentang Pembentukan Peraturan Perundang-Undangan.

Peraturan adalah dasar dari negara hukum, negara yang pemerintahannya tunduk pada hukum, khususnya Undang-undang. Para ahli biasa membedakan antara Undang-Undang dalam arti materiel (wet ini materiele zin) dan Undang-undang dalam arti formil (wet ini formele zin). Pengertian Undang-undang dalam arti materiel itu menyangkut Undang-undang yang dilihat dari segi isi, materi, dan substansinya sedangkan Undangu-undang dalam arti formil dilihat dari segi bentuk dan pembentukannya. Pembedaan keduanya dapat dilihat hanya dari segi penekanan atau sudut penglihatan, yaitu suatu Undang-undang dapat dilihat dari segi materinya atau dilihat dari segi bentuknya, yang dapat dilihat sebagai dua hal yang sama sekali terpisah.

Menurut I.C van der Vies, masalah bagaimana suatu Undang-undang harus dibuat terutama mengenai syarat-syarat yang wajib dipenuhi oleh pembuat Undang-undang. Syarat-syarat ini dapat diringkaskan sebagai "asas-asas pembuatan peraturan yang baik". Asas-asas ini mempunyai kaitan dengan berbagai aspek pembuatan peraturan, yaitu asas-asas yang berkaitan dengan "bagaimana" dan asas-asas yang berkaitan dengan "apa"-nya suatu keputusan yang masingmasing disebut asas-asas formal dan asas-asas material. 
Berdasarkan pendapat dan ketentuan yang telah disampaikan di atas akan dikemukakan beberapa pandangan dan analisa terhadap Undang-undang Nomor 12 Tahun 2011 Tentang Pembentukan Peraturan Perundang-Undangan (Undang-undang). Secara umum isi Undang-undang dapat dikatakan merupakan keharusan (obligatere) sehingga seluruh ketentuan dalam Undang-undang harus dilaksanakan. Jika Undang-undang tidak dilaksanakan maka Undang-undang ini dapat dikatakan tidak berwibawa.

Dalam Pasal 5 Undang-undang disebutkan bahwa dalam membentuk Peraturan Perundang-undangan harus dilakukan berdasarkan pada asas Pembentukan Peraturan Perundang-undangan yang baik, yang meliputi:
a. kejelasan tujuan;
b. kelembagaan atau pejabat pembentuk yang tepat;
c. kesesuaian antara jenis, hierarki, dan materi muatan;
d. dapat dilaksanakan;
e. kedayagunaan dan kehasilgunaan;
f. kejelasan rumusan; dan
g. keterbukaan.

Kemudian dalam Pasal 6 ayat (1) Undang-undang disebutkan bahwa materi muatan Peraturan Perundang-undangan harus mencerminkan asas:
a. pengayoman;
b. kemanusiaan;
c. kebangsaan;
d. kekeluargaan;
e. kenusantaraan;
f. bhinneka tunggal ika;
g. keadilan;
h. kesamaan kedudukan dalam hukum dan pemerintahan;
i. ketertiban dan kepastian hukum; dan/atau
j. keseimbangan, keserasian, dan keselarasan.

Selanjutnya dalam Pasal 6 ayat (2) dinyatakan bahwa selain mencerminkan asas sebagaimana dimaksud pada ayat (1), Peraturan Perundang-undangan tertentu dapat berisi asas lain 
sesuai dengan bidang hukum peraturan perundang-undangan yang bersangkutan.

Kedua Pasal tersebut berisi asas-asas formal dan material yang harus dilaksanakan dalam pembentukan setiap peraturan Perundang-undangan di Indonesia. Sebagaimana telah disampaikan isi Undang-undang secara umum dapat dikatakan merupakan keharusan sehingga dalam setiap pembentukan peraturan Perundang-undangan di Indonesia asas-asas tersebut harus ditaati tanpa pengecualian apapun.

Sebagai sebuah Undang-undang yang menjadi peraturan dalam rangka pembentukan peraturan Perundang-undangan dapat dikatakan sudah baik. Jika saja setiap orang yang terlibat dalam pembentukan peraturan Perundang-undangan mau mempelajari dan melaksanakan Undang-undang maka tidak akan mengalami banyak kesulitan lagi terlebih dengan keberadaan lampiran yang sangat mendetail.

- $\quad$ Undang-Undang Republik Indonesia Nomor 6 Tahun 2014 Tentang Desa.

Pasal 69

(1) Jenis peraturan di Desa terdiri atas Peraturan Desa, peraturan bersama Kepala Desa, dan peraturan Kepala Desa.

(2) Peraturan sebagaimana dimaksud pada ayat (1) dilarang bertentangan dengan kepentingan umum dan/atau ketentuan peraturan perundang-undangan yang lebih tinggi.

(3) Peraturan Desa ditetapkan oleh Kepala Desa setelah dibahas dan disepakati bersama Badan Permusyawaratan Desa.

(4) Rancangan Peraturan Desa tentang Anggaran Pendapatan dan Belanja Desa, pungutan, tata ruang, dan organisasi Pemerintah Desa harus mendapatkan evaluasi dari Bupati/Walikota sebelum ditetapkan menjadi Peraturan Desa. 
(5) Hasil evaluasi sebagaimana dimaksud pada ayat (4) diserahkan oleh Bupati/Walikota paling lama 20 (dua puluh) hari kerja terhitung sejak diterimanya rancangan peraturan tersebut oleh Bupati/Walikota.

(6) Dalam hal Bupati/Walikota telah memberikan hasil evaluasi sebagaimana dimaksud pada ayat (5), Kepala Desa wajib memperbaikinya.

(7) Kepala Desa diberi waktu paling lama 20 (dua puluh) hari sejak diterimanya hasil evaluasi untuk melakukan koreksi.

(8) Dalam hal Bupati/Walikota tidak memberikan hasil evaluasi dalam batas waktu sebagaimana dimaksud pada ayat (5), Peraturan Desa tersebut berlaku dengan sendirinya.

(9) Rancangan Peraturan Desa wajib dikonsultasikan kepada masyarakat Desa.

(10) Masyarakat Desa berhak memberikan masukan terhadap Rancangan Peraturan Desa.

(11) Peraturan Desa dan peraturan Kepala Desa diundangkan dalam Lembaran Desa dan Berita Desa oleh sekretaris Desa.

(12) Dalam pelaksanaan Peraturan Desa sebagaimana dimaksud pada ayat (1), Kepala Desa menetapkan Peraturan Kepala Desa sebagai aturan pelaksanaannya.

Pasal 70

(1) Peraturan bersama Kepala Desa merupakan peraturan yang ditetapkan oleh Kepala Desa dari 2 (dua) Desa atau lebih yang melakukan kerja sama antar-Desa.

(2) Peraturan bersama Kepala Desa sebagaimana dimaksud pada ayat (1) merupakan perpaduan kepentingan Desa masingmasing dalam kerja sama antar-Desa.

Undang-Undang Republik Indonesia Nomor 23 Tahun 2014 Tentang Pemerintahan Daerah. 


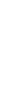

Dalam melaksanakan urusan pemerintahan yang menjadi kewenangan daerah, Kepala Daerah dan DPRD selaku penyelenggara Pemerintahan Daerah membuat Peraturan daerah sebagai dasar hukum bagi daerah dalam menyelanggarakan otonomi daerah sesuai dengan kondisi dan aspirasi masyarakat serta kekhasan dari daerah tersebut. Peraturan daerah yang dibuat oleh daerah hanya berlaku dalam batas-batas yurisdiksi daerah yang bersangkutan.

Walaupun demikian Peraturan daerah yang ditetapkan oleh daerah tidak boleh bertentangan dengan ketentuan peraturan Perundangundangan yang lebih tinggi tingkatannya sesuai dengan hierarki peraturan Perundang-undangan. Disamping itu Peraturan daerah sebagai bagian dari sistem peraturan perundang-undangan tidak boleh bertentangan dengan kepentingan umum sebagaimana diatur dalam kaidah penyusunan Peraturan Daerah.

Daerah melaksanakan otonomi daerah yang berasal dari kewenangan Presiden yang memegang kekuasaan pemerintahan. Mengingat tanggung jawab akhir penyelenggaraan pemerintahan ada di tangan Presiden, maka konsekuensi logisnya kewenangan untuk membatalkan Peraturan daerah ada di tangan Presiden. Adalah tidak efisien apabila Presiden yang langsung membatalkan Peraturan Daerah. Presiden melimpahkan kewenangan pembatalan Peraturan daerah Propinsi kepada Menteri sebagai pembantu Presiden yang bertanggung jawab atas Otonomi Daerah. Sedangkan untuk membatalkan Peraturan daerah Kabupaten/Kota, Presiden melimpahkan kewenangannya kepada Gubernur selaku Wakil Pemerintah Pusat di Daerah.

Untuk menghindari terjadinya kesewenang-wenangan dalam pembatalan Peraturan daerah, maka Pemerintah Daerah Provinsi dapat mengajukan keberatan pembatalan Peraturan Daerah Provinsi yang dilakukan oleh Menteri kepada Presiden. Sedangkan Pemerintah Daerah Kabupaten/Kota dapat mengajukan keberatan 
pembatalan Peraturan Daerah Kabupaten/Kota yang dilakukan Gubernur sebagai wakil pemerintah pusat kepada Menteri. Dari sisi penyelenggaraan Pemerintahan Daerah, keputusan yang diambil oleh Presiden dan Menteri bersifat final.

Dalam rangka menciptakan tertib adminstrasi pelaporan Peraturan daerah, setiap Peraturan daerah yang akan diundangkan harus mendapatkan nomor registrasi terlebih dahulu. Peraturan Daerah Provinsi harus mendapatkan nomor register dari kementerian, sedangkan Peraturan daerah Kabupaten/Kota mendapatkan nomor register dari gubernur sebagai wakil Pemerintah Pusat. Dengan adanya pemberian nomor register tersebut akan terhimpun informasi mengenai keseluruhan Peraturan daerah yang dibentuk oleh Daerah dan sekaligus juga informasi Peraturan daerah secara Nasional.

- $\quad$ Peraturan Pemerintah Republik Indonesia Nomor 43 Tahun 2014 Tentang Peraturan Pelaksanaan Undang-Undang Nomor 6 Tahun 2014 Tentang Desa.

Pasal 83

(1) Rancangan peraturan Desa diprakarsai oleh Pemerintah Desa.

(2) Badan Permusyawaratan Desa dapat mengusulkan rancangan peraturan Desa kepada pemerintah desa.

(3) Rancangan peraturan Desa sebagaimana dimaksud pada ayat (1) dan ayat (2) wajib dikonsultasikan kepada masyarakat Desa untuk mendapatkan masukan.

(4) Rancangan peraturan Desa sebagaimana dimaksud pada ayat (2) ditetapkan oleh kepala Desa setelah dibahas dan disepakati bersama Badan Permusyawaratan Desa.

Pasal 84

(1) Rancangan peraturan Desa yang telah disepakati bersama disampaikan oleh pimpinan Badan Permusyawaratan Desa kepada kepala Desa untuk ditetapkan menjadi peraturan Desa 
paling lambat 7 (tujuh) Hari terhitung sejak tanggal kesepakatan.

(2) Rancangan peraturan Desa sebagaimana dimaksud pada ayat (1) wajib ditetapkan oleh kepala Desa dengan membubuhkan tanda tangan paling lambat 15 (lima belas) Hari terhitung sejak diterimanya rancangan peraturan Desa dari pimpinan Badan Permusyawaratan Desa.

(3) Peraturan Desa dinyatakan mulai berlaku dan mempunyai kekuatan hukum yang mengikat sejak diundangkan dalam lembaran Desa dan berita Desa oleh sekretaris Desa.

(4) Peraturan Desa yang telah diundangkan sebagaimana dimaksud pada ayat (3) disampaikan kepada bupati/walikota sebagai bahan pembinaan dan pengawasan paling lambat 7 (tujuh) Hari setelah diundangkan.

(5) Peraturan Desa wajib disebarluaskan oleh Pemerintah Desa Pasal 85

Peraturan kepala Desa merupakan peraturan pelaksanaan peraturan Desa.

Pasal 86

(1) Peraturan kepala Desa ditandatangani oleh kepala Desa.

(2) Peraturan kepala Desa sebagaimana dimaksud pada ayat (1) diundangkan oleh sekretaris Desa dalam lembaran Desa dan berita Desa.

(3) Peraturan kepala Desa wajib disebarluaskan oleh Pemerintah Desa.

\section{Pasal 87}

Peraturan Desa dan peraturan kepala Desa yang bertentangan dengan kepentingan umum dan/atau ketentuan peraturan perundang-undangan yang lebih tinggi dibatalkan oleh bupati/walikota.

Pasal 88 
(1) Peraturan bersama kepala Desa merupakan peraturan kepala Desa dalam rangka kerja sama antar-Desa.

(2) Peraturan bersama kepala Desa ditandatangani oleh kepala Desa dari 2 (dua) Desa atau lebih yang melakukan kerja sama antar-Desa.

(3) Peraturan bersama kepala Desa disebarluaskan kepada masyarakat Desa masing-masing.

Pasal 89

Pedoman teknis mengenai peraturan di Desa diatur dengan Peraturan Menteri.

Peraturan Menteri Dalam Negeri Nomor 111 Tahun 2014 tentang Pedoman Tehnis Penyusunan Peraturan di Desa.

Pasal 4

(1) Peraturan Desa sebagaimana dimaksud dalam Pasal 2 huruf a berisi materi pelaksanaan kewenangan desa dan penjabaran lebih lanjut dari Peraturan Perundang-undangan yang lebih tinggi.

(2) Peraturan bersama Kepala Desa sebagaimana dimaksud dalam Pasal 2 huruf b berisi materi kerjasama desa.

(3) Peraturan Kepala Desa sebagaimana dimaksud dalam Pasal 2 huruf c berisi materi pelaksanaan peraturan desa, peraturan bersama kepala desa dan tindak lanjut dari peraturan perundang-undangan yang lebih tinggi.

Pasal 5

(1) Perencanaan penyusunan rancangan Peraturan Desa ditetapkan oleh Kepala Desa dan BPD dalam rencana kerja Pemerintah Desa.

(2) Lembaga kemasyarakatan, lembaga adat dan lembaga desa lainnya di desa dapat memberikan masukan kepada Pemerintah Desa dan atau BPD untuk rencana penyusunan rancangan Peraturan Desa. 
Pasal 6

(1) Penyusunan rancangan Peraturan Desa diprakarsai oleh Pemerintah Desa.

(2) Rancangan Peraturan Desa yang telah disusun, wajib dikonsultasikan kepada masyarakat desa dan dapat dikonsultasikan kepada camat untuk mendapatkan masukan.

(3) Rancangan Peraturan Desa yang dikonsultasikan sebagaimana dimaksud pada ayat (2) diutamakan kepada masyarakat atau kelompok masyarakat yang terkait langsung dengan substansi materi pengaturan.

(4) Masukan dari masyarakat desa dan camat sebagaimana dimaksud pada ayat (2) digunakan Pemerintah Desa untuk tindaklanjut proses penyusunan rancangan Peraturan Desa.

(5) Rancangan Peraturan Desa yang telah dikonsultasikan sebagaimana dimaksud pada ayat (3) disampaikan Kepala Desa kepada BPD untuk dibahas dan disepakati bersama.

Pasal 7

(1) BPD dapat menyusun dan mengusulkan rancangan Peraturan Desa.

(2) Rancangan Peraturan Desa sebagaimana dimaksud pada ayat (1) kecuali untuk rancangan Peraturan Desa tentang rencana pembangunan jangka menengah Desa, rancangan Peraturan Desa tentang rencana kerja Pemerintah Desa, rancangan Peraturan Desa tentang APB Desa dan rancangan Peraturan Desa tentang laporan pertanggungjawaban realisasi pelaksanaan APB Desa.

(3) Rancangan Peraturan Desa sebagaimana dimaksud pada ayat (1) dapat diusulkan oleh anggota BPD kepada pimpinan BPD untuk ditetapkan sebagai rancangan Peraturan Desa usulan BPD. 
Pasal 8

(1) BPD mengundang Kepala Desa untuk membahas dan menyepakati rancangan Peraturan Desa.

(2) Dalam hal terdapat rancangan Peraturan Desa prakarsa Pemerintah Desa dan usulan BPD mengenai hal yang sama untuk dibahas dalam waktu pembahasan yang sama, maka didahulukan rancangan Peraturan Desa usulan BPD sedangkan Rancangan Peraturan Desa usulan Kepala Desa digunakan sebagai bahan untuk dipersandingkan.

Pasal 9

(1) Rancangan Peraturan Desa yang belum dibahas dapat ditarik kembali oleh pengusul.

(2) Rancangan Peraturan Desa yang telah dibahas tidak dapat ditarik kembali kecuali atas kesepakatan bersama antara Pemerintah Desa dan BPD.

Pasal 10

(1) Rancangan peraturan Desa yang telah disepakati bersama disampaikan oleh pimpinan Badan Permusyawaratan Desa kepada kepala Desa untuk ditetapkan menjadi peraturan Desa paling lambat 7 (tujuh) Hari terhitung sejak tanggal kesepakatan.

(2) Rancangan peraturan Desa sebagaimana dimaksud pada ayat (1) wajib ditetapkan oleh kepala Desa dengan membubuhkan tanda tangan paling lambat 15 (lima belas) Hari terhitung sejak diterimanya rancangan peraturan Desa dari pimpinan Badan Permusyawaratan Desa.

Pasal 11

(1) Rancangan Peraturan Desa yang telah dibubuhi tanda tangan sebagaimana dimaksud pada ayat (1) disampaikan kepada Sekretaris Desa untuk diundangkan. 
(2) Dalam hal Kepala Desa tidak menandatangani Rancangan Peraturan Desa sebagaimana dimaksud pada ayat (1), Rancangan Peraturan Desa tersebut wajib diundangkan dalam Lembaran Desa dan sah menjadi Peraturan Desa.

Pasal 12

(1) Sekretaris Desa mengundangkan peraturan desa dalam lembaran desa.

(2) Peraturan Desa dinyatakan mulai berlaku dan mempunyai kekuatan hukum yang mengikat sejak diundangkan.

Pasal 13

(1) Penyebarluasan dilakukan oleh Pemerintah Desa dan BPD sejak penetapan rencana penyusunan rancangan Peraturan Desa, penyusunan Rancangan Peratuan Desa, pembahasan Rancangan Peraturan Desa, hingga Pengundangan Peraturan Desa.

(2) Penyebarluasan sebagaimana dimaksud pada ayat (1) dilakukan untuk memberikan informasi dan/atau memperoleh masukan masyarakat dan para pemangku kepentingan.

Pasal 24

Pembahasan rancangan Peraturan Bersama Kepala Desa dilakukan oleh 2 (dua) Kepala Desa atau lebih.

Pasal 25

(1) Kepala Desa yang melakukan kerja sama antar-Desa menetapkan Rancangan Peraturan Desa dengan membubuhkan tanda tangan paling lambat 7 (tujuh) hari terhitung sejak tanggal disepakati.

(2) Rancangan Peraturan Bersama Kepala Desa yang telah dibubuhi tanda tangan sebagaimana dimaksud pada ayat (1) diundangkan dalam Berita Desa oleh Sekretaris Desa masingmasing desa. 
(3) Peraturan Bersama Kepala Desa sebagaimana dimaksud pada ayat 1 mulai berlaku dan mempunyai kekuatan hukum mengikat sejak tanggal diundangkan dalam Berita Desa pada masing-masing Desa.

Pasal 26

Peraturan Bersama Kepala Desa disebarluaskan kepada masyarakat Desa masing-masing.

Pasal 27

(1) Penyusunan rancangan Peraturan Kepala Desa dilakukan oleh Kepala Desa.

(2) Materi muatan Peraturan Kepala Desa meliputi materi pelaksanaan Peraturan di Desa dan peraturan perundangundangan yang lebih tinggi.

Pasal 28

Peraturan Kepala Desa diundangkan dalam Berita Desa oleh Sekretaris Desa

Pasal 29

Pembiayaan pembentukan Peraturan di Desa dibebankan pada APB Desa.

Pasal 30

Tentang Peraturan Desa Adat diatur dalam ketentuan lain-lain di Pasal 30 (ayat) 1 disebutkan bahwa

(1) Peraturan Desa Adat disesuaikan dengan hukum adat dan norma adat istiadat yang berlaku di Desa Adat sepanjang tidak bertentangan dengan ketentuan Peraturan Perundangundangan. Dijelaskan juga dalam ayat selanjutnya bahwa

(2) Teknik dan prosedur penyusunan Peraturan di desa yang diatur dalam Peraturan Menteri ini berlaku secara mutatis mutandis bagi teknik dan prosedur penyusunan Peraturan di desa adat. 


\section{|}

BAB IV

LANDASAN FILOSOFIS, YURIDIS, DAN SOSIOLOGIS

\section{A. Landasan Filosofis}

Untuk memperoleh hasil yang optimal dalam program pembangunan desa, maka harus mendapat dukungan dari masyarakat. Karena itu, maka proses pembangunan yang diawali dari sebuah perencanaan, pelaksanaan, monitoring dan evaluasi akan lebih baik apabila melibatkan masyarakat. Tuntutan ke arah itu semakin lama semakin nyaring terdengar di tengah era keterbukaan sekarang ini, dan oleh karena itu tuntutan tersebut sebaiknya disambut oleh penyelenggara pemerintahan desa dan dipayungi oleh sebuah regulasi (perdes).

Winterton dalam Peter de Cruz yang diterjemahkan oleh Narulita Yusron yaitu, sistem hukum merupakan sekumpulan peraturan dan institusi dari suatu negara, sedangkan arti sistem hukum yang lebih luas adalah teknik atau cara-cara yang digunakan oleh sejumlah negara, dimana sistem hukumnya memiliki kesamaan secara umum(de Cruz, 2010: 4-5). Menurut Sudikno Mertokusumo dalam Efran Helmi Juni (2012 : 275) sistem hukum adalah tatanan atau kesatuan yang utuh mengenai kaidah-kaidah atau pernyataan tentang apa yang seharusnya, sehingga sistem hukum merupakan sistem yang normatif. Istilah sistem Menurut Harijono Djojodihardjo adalah sekumpulan objek yang mencakup hubungan fungsional antara tiap-tiap objek dan hubungan antara ciri tiap objek, dan secara keseluruhan merupakan suatu kesatuan secara fungsional. Kemudian, Sistem menurut Lani Sidharta merupakan himpunan dari bagian-bagian yang saling berhubungan yang secara bersama mencapai tujuan-tujuan yang sama. Pamudji dalam Syafiie (2003: 1) pengertian sistem merupakan suatu kebulatan atau keseluruhan yang kompleks atau terorganisir, suatu himpunan atau perpaduan hal-hal atau bagian-bagian yang membentuk suatu kebulatan atau 
keseluruhan yang kompleks atau utuh. Kemudian, John Mc Manama (http://www.anneahira.com) mempunyai pendapat lain mengenai sistem yaitu sebuah struktur konseptual yang tersusun dari fungsifungsi yang saling berhubungan yang bekerja sebagai suatu kesatuan organik untuk mencapai suatu hasil yang diinginkan secara efektif dan efisien ${ }^{10}$.

Menurut C.W. Paton, yang dikutip oleh Muhadi, dalam bukunya A Textbook of Jurisprudence, 1969, mengatakan asas adalah: $A$ principles is the broad reason, which lies at the base of rule of law dalam bahasa indonesia, kalimat itu berbunyi: asas adalah suatu alam pikiran yang dirumuskan secara luas dan mendasari adanya sesuatu norma hukum. Disingkatnya bahwa dalam unsur-unsur asas sebagai berikut.
a. Alam pikiran
b. Rumusan luas
c. Dasar bagi pembentukan norma hukum

Jadi Asas ialah suatu alam pikiran, yang melatarbelakangi pemberontakan norma hukum. Rumusan asas yang dihidangkan oleh Paton memberi kesan, seolah-olah tiap norma hukum dapat dikembalikam kepada susunan asas. Dalam praktek terdapat norma-norma hukum, yang tidak dapat ditelusuri bagaimana bunyi asas yang mendasarinya. Salah satu contoh, norma hukum positif dalam bidang lalu lintas, yang menyuruh pemakai jalan umum yang mempergunakan bagian kiri dari jalan itu. Untuk norma hukum itu sulit dicarikan asasnya, tetapi kalau ia menjadi asas maka norma hukum itu sendirilah yang berfungsi sebagai asas ${ }^{11}$.

Asas hukum memang bukan merupakan aturan hukum, karena asas hukum tidak dapat dilaksanakan/ dioperasikan langsung terhadap suatu peristiwa dengan menganggapnya sebagai

http://e-journal.uajy.ac.id/6944/3/MIH202042.pdf

11 Mahadi, Pembentukan Hukum Nasional dan Permasalahannya, Alumni, Bandung, 1981., hal 54 
bagian dari aturan umum, tetapi harus dengan penyesuaian substansi, untuk itu diperlukan isi yang lebih konkrit.

Asas-asas hukum umum bagi penyelenggaran pemerintahan yang patut (algemene beginselen van behoorlijk best Undangundang) dimana asas ini tumbuh dalam rangka mencari cara-cara untuk melakukan pengawasan atau kontrol yang sesuai hukum (rechtmatigheidscontrole) terhadap tindakan-tindakan pemerintahan, terutama yang dapat dilakukan oleh hakim yang bebas. Asas-asas tersebut dirasakan akan bertambah penting apabila dalam memenuhi tuntutan terselenggaranya kesejahteraan rakyat diperlukan banyak peraturan perundangundangan yang memberikan keleluasaan yang besar kepada aparatur pemerintahan. Dengan demikian maka terhadap aspekaspek kebijakan dari keputusan-keputusan pemerintah yang tidak dibatasi oleh peraturan perundang-undangan dapat dilakukan pengujian oleh hakim (rechterlijke toetsing), tanpa perlu hakim tersebut menguji kebijakan pemerintahan yang diberikan oleh peraturan perundang-undangan itu sendiri.

Asas-asas pembentukan peraturan perundangundangan yang baik menurut I.C. van der Vlies dalam bukunya yang berjudul Handboek Wetgeving dibagi dalam dua kelompok yaitu: ${ }^{12}$

a. Asas-asas formil:

1) Asas tujuan yang jelas (beginsel van duidelijke doelstelling), yakni setiap pembentukan peraturan perundang-undangan harus mempunyai tujuan dan manfaat yang jelas untuk apa dibuat;

2) Asas organ/lembaga yang tepat (beginsel van het juiste orgaan), yakni setiap jenis peraturan perundang-undangan harus dibuat oleh lembaga atau organ pembentuk peraturan

2 Maria Farida Indrati Soeprapto, Ilmu Perundang-undangan:Dasar-dasar dan Pembentukannya, hal 34 
perundag-undagan yang berwenang; peraturan perundangundangan tersebut dapat dibatalkan (vernietegbaar) atau batal demi hukum (vanrechtswege nieteg), bila dibuat oleh lembaga atau organ yang tidak berwenang;

3) Asas kedesakan pembuatan pengaturan (het noodzakelijkheidsbeginsel);

4) Asas kedapatlaksanaan (dapat dilaksanakan) (het beginsel van uitvoerbaarheid), yakni setiap pembentukan peraturan perundang-undangan harus didasarkan pada perhitungan bahwa peraturan perundang-undangan yang dibentuk nantinya dapat berlaku secara efektif di masyarakat karena telah mendapat dukungan baik secara filosofis, yuridis, maupun sosiologis sejak tahap penyusunannya.

5) Asas konsensus (het beginsel van de consensus).

b. Asas-asas materiil:

1) Asas terminologi dan sistematika yang benar (het beginsel van duidelijke terminologie en duidelijke systematiek);

2) Asas dapat dikenali (het beginsel van de kenbaarheid);

3) Asas perlakuan yang sama dalam hukum (het rechtsgelijkheidsbeginsel);

4) Asas kepastian hukum (het rechtszekerheidsbeginsel);

5) Asas pelaksanaan hukum sesuai dengan keadaan individual (het beginsel van de individuele rechtsbedeling).

Selain itu Undang-Undang Republik Indonesia Nomor 12 Tahun 2011 tentang Pembentukan Peraturan Perundang-undangan, mengingatkan kepada pembentuk undang-undang agar selalu memperhatikan asas pembentukan peraturan perundang-undangan yang baik dan asas materi muatan.

Dalam membentuk Peraturan Perundang-undangan harus dilakukan berdasarkan pada asas Pembentukan Peraturan Perundang-undangan yang baik, yang meliputi: 
a. "asas kejelasan tujuan”, bahwa setiap Pembentukan Peraturan Perundang-undangan harus mempunyai tujuan yang jelas yang hendak dicapai;

b. "asas kelembagaan atau pejabat pembentuk yang tepat" , bahwa setiap jenis Peraturan Perundang-undangan harus dibuat oleh lembaga negara atau pejabat Pembentuk Peraturan Perundang-undangan yang berwenang. Peraturan Perundangundangan tersebut dapat dibatalkan atau batal demi hukum apabila dibuat oleh lembaga negara atau pejabat yang tidak berwenang;

c. "asas kesesuaian antara jenis, hierarki, dan materi muatan", bahwa dalam Pembentukan Peraturan Perundang-undangan harus benarbenar memperhatikan materi muatan yang tepat sesuai dengan jenis dan hierarki Peraturan Perundangundangan;

d. "asas dapat dilaksanakan", bahwa setiap Pembentukan Peraturan Perundang-undangan harus memperhitungkan efektivitas Peraturan Perundangundangan tersebut di dalam masyarakat, baik secara filosofis, sosiologis, maupun yuridis;

e. "asas kedayagunaan dan kehasilgunaan", bahwa setiap Peraturan perundang-undangan dibuat karena memang benarbenar dibutuhkan dan bermanfaat dalam mengatur kehidupan bermasyarakat, berbangsa, dan bernegara;

f. “asas kejelasan rumusan”, bahwa setiap Peraturan Perundangundangan harus memenuhi persyaratan teknis penyusunan Peraturan Perundang-undangan, sistematika, pilihan kata atau istilah, serta bahasa hukum yang jelas dan mudah dimengerti sehingga tidak menimbulkan berbagai macam interpretasi dalam pelaksanaannya;

g. “asas keterbukaan”, bahwa dalam Pembentukan Peraturan Perundang-undangan mulai dari perencanaan, penyusunan, 


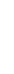

pembahasan, pengesahan atau penetapan, dan pengundangan bersifat transparan dan terbuka.

Dengan demikian, seluruh lapisan masyarakat mempunyai kesempatan yang seluas-luasnya untuk memberikan masukan dalam Pembentukan Peraturan Perundang-undangan.

Dalam Pasal 6 Undang-Undang Nomor 12 Tahun 2011, digunakan asas-asas yang dipakai sebagai materi muatan Peraturan Perundangundangan yaitu:

a. Pengayoman

Adalah bahwa setiap materi muatan Peraturan Perundangundangan harus berfungsi memberikan perlindungan dalam rangka menciptakan ketentraman masyarakat.

b. Kemanusiaan

Adalah bahwa setiap materi muatan Peraturan Perundangundangan harus mencerminkan perlindungan dan penghormatan hak-hak asasi manusia serta harkat dan martabat setiap warga negara dan penduduk Indonesia secara proporsional.

c. Kebangsaan

Adalah bahwa setiap materi muatan Peraturan Perundangundangan harus mencerminkan sifat dan watak bangsa Indonesia yang pluralistik (kebhinekaan) dengan tetap menjaga prinsip Negara Kesatuan Republik Indonesia.

d. Kekeluargaan

Adalah bahwa setiap materi muatan Peraturan PerundangUndangan harus mencerminkan musyawarah untuk mencapai mufakat dalam setiap pengambilan keputusan.

e. Kenusantaraan

Adalah bahwa setiap materi muatan peraturan perundangundangan senantiasa memperhatikan kepentingan seiuruh wilayah Indonesia dan materi muatan peraturan perundang- 
undangan yang dibuat di daerah merupakan bagian dari sistem hukum nasional yang berdasarkan Pancasila.

f. Bhineka Tunggal Ika

Adalah bahwa materi muatan Peraturan Perundang-undangan harus memperhatikan keragaman penduduk, agama, suku dan golongan, Kondisi khusus daerah dan budaya khususnya yang menyangkut masalah-masalah sensitif dalam kehidupan bermasyarakat, berbangsa dan bemegara.

g. Keadilan

Adalah bahwa materi muatan Peraturan Perundang-undangan harus mencerminkan keadilan secara proporsional bagi setiap warga negara tanpa kecuali.

h. Kesamaan kedudukan dalam hukum dan pemerintahan.

Adalah bahwa materi muatan Peraturan Pemndang-undangan tidak boleh berisi hal-hal yang bersifat membedakan berdasarkan latar belakang antara lain agama, suku, ras, golongan,. gender, atau status sosial.

i. Ketertiban dan kepastian hukum

Adalah bahwa materi muatan Peraturan Perundang-undangan harus dapat menimbulkan ketertiban dalam masyarakat melalui jaminan adanya kepastian hukum.

j. Keseimbangan, keserasian dan keselarasan

Adalah bahwa setiap materi muatan Peraturan PerundangUndangan harus mencerminkan keseimbangan, keserasian, antara kepentingan individu dan masyarakat dengan kepentingan bangsa dan negara ${ }^{13}$.

Bagian Pemerintahan Desa Dan Kelurahan Sekretariat Daerah Kabupaten Karanganyar Tahun 2014 


\section{B. Landasan Yuridis}

Salah satu perbedaan yang terkandung dalam Undang-undang Nomor 6 tahun 2014 adalah diakomodirnya partisipasi masyarakat, yang mana merupakan hal baru dalam pengaturan mengenai desa di Indonesia. Hal tersebut dibuktikan dengan adanya asas kebersamaan, demokrasi, dan khususnya partisipasi.

Asas partisipasi, sebagaimana diatur dalam Pasal 3 butir (j) Undangundang Nomor 6 Tahun 2014 mempunyai pengertian yakni “turut berperan aktif dalam suatu kegiatan"14. Diakomodasinya asas kemudian diwujudkan dalam tujuan pengaturan desa sebagaimana yang diatur dalam Pasal 4. Dalam pasal 4 butir (d) misalnya disebutkan bahwa salah satu tujuan pengaturan desa dalam Undang-undang Nomor 6 tahun 2014 adalah "untuk mendorong prakarsa, gerakan, dan partisipasi masyarakat desa untuk pengembangan potensi dan Aset Desa guna kesejahteraan bersama”. Selanjutnya, dalam Pasal 4 butir (i) juga disebutkan bahwa tujuan pengaturan desa adalah untuk "memperkuat masyarakat desa sebagai subjek pembangunan" Perwujudan asas partisipasi tersebut juga terdapat dalam bagian hak dan kewajiban masyarakat desa dalam Undang-undang Nomor 6 Tahun 2014 Tentang Desa, sebagaimana disebutkan dalam Pasal 68 yang mengatur hak dan kewajiban masyarakat desa sehingga mampu menunjang sebuah kesatuan masyarakat yang partisipatif. Kemudian, sebagai tindak lanjut dari diakomodasinya asas partisipasi, Undang-undang Nomor 6 Tahun 2014 mengakomodasi berbagai bentuk partisipasi masyarakat dalam berbagai hal yang menyangkut desa dan pemerintahan desa. Adanya pengakomodiran tersebut dilakukan untuk mengubah makna partisipasi yang selama ini lebih dianggap sebagai sebuah proses mobilisasi masyarakat

14 Bagian Penjelasan Asas Pengaturan dalam Undang-Undang Nomor 6 Tahun 2014 Tentang Desa 
untuk kepentingan pembangunan dengan mengatasnamakan "kesukarelaan berkorban demi bangsa dan negara"15.

Pengaturan dan pengakomodiran berbagai bentuk partisipasi tersebut dilandasi adanya otonomi yang telah dimiliki desa sejak dahulu. Dalam sidang pembahasan Naskah Undang-Undang Dasar pada tahun 1945 oleh BPUPKI, otonomi di desa tersebut, sebagaimana dikatakan oleh salah satu anggota penyusun Naskah Undang-Undang Dasar 1945 yakni Muhammad Yamin. Yamin beranggapan bahwa badan-badan masyarakat seperti desa merupakan susunan pemerintah yang paling bawah, yang ia sebut sebagai perintah bawahan ${ }^{16}$. Lebih lanjut, Yamin juga menyatakan bahwa otonomi yang dimiliki desa merupakan sebuah susunan persekutuan-persekutuan otonom yang mengagumkan yang tidak rusak dan begitu kuat sehingga tidak dapat diruntuhkan oleh pengaruh Hindu, pengaruh feodalisme, bahkan pengaruh Eropa yang menjajah Indonesia ${ }^{17}$.

Salah satu cara yang hendak digunakan oleh Undang-Undang Nomor 6 Tahun 2014 Tentang Desa dalam mencapai tujuan tersebut adalah dengan mengakomodir partisipasi masyarakat dalam berbagai pasal yang ada dalam Undang-Undang Nomor 6 Tahun 2014 Tentang Desa. Undang-Undang Nomor 6 Tahun 2014 Tentang Desa memberi porsi besar bagi masyarakat desa dalam mengelola dan mengembangkan desa mereka, diantaranya adanya peran masyarakat dalam pemerintahan desa maupun dalam pembangunan desa. Secara umum, tujuan dari diakomodirnya partisipasi masyarakat sebagaimana disebutkan pada Pasal 4 huruf (d) dan (i) Undang-undang Nomor 6 tahun 2014 tentang Desa, memiliki pandangan yang sama dengan tujuan pengaturan mengenai desa pada umumnya, yakni untuk mewujudkan kesejahteraan bersama

15 AAGN Ari Dwipayana \& Sutoro Eko, Membangun Good Governance di Desa, IRE Press, Yogyakarta, 2003, hlm 105

16 Muhammad Yamin, Naskah Persiapan Undang-Undang Dasar 1945, Yayasan Prapanca, 1959, hlm 230

17 Muhammad Yamin, Naskah Persiapan Undang-Undang Dasar 1945, ibid, hlm 96 
dalam masyarakat desa, dan menjadikan masyarakat desa sebagai subjek dalam pembangunan desa ${ }^{18}$.

\section{Landasan Sosiologis}

Peraturan Desa yaitu produk hukum tingkat desa yang ditetapkan oleh kepala desa bersama badan permusyawaratan desa dalam rangka penyelenggaraan pemerintahan desa. Peraturan desa dibentuk dalam rangka penyelenggaraan pemerintahan desa, dengan demikian maka pemerintahan desa harus merupakan penjabaran lebih lanjut dari peraturan-peraturan perundangundangan yang lebih tinggi dan tidak boleh bertentangan dengan kepentingan umum dan/atau peraturan perundang-undangan yang lebih tinggi serta harus memperhatikan kondisi sosial budaya masyarakat desa setempat dalam upaya mencapai tujuan pemerintahan, pembangunan dan pelayanan masyarakat jangka panjang, menengah dan jangka pendek.

Peraturan perundang-undangan merupakan peraturan tertulis yang memuat norma hukum yang mengikat secara umum dan dibentuk atau ditetapkan oleh lembaga negara atau pejabat yang berwenang melalui prosedur yang ditetapkan dalam perundangundangan. Peraturan perundang-undangan dibuat untuk melindungi dan mengayomi hak-hak warga negara (Pasal 1 angka 2 UU no. 12 tahun 2011). Selain itu peraturan perundang-undangan menjadi hal yang sangat penting bagi warga negara karena dapat menciptakan ketertiban dan ketenteraman dalam kehidupan bermasyarakat. Penyusunan peraturan perundang-undangan bukan saja mengacu pada tujuannya untuk melindungi dan mengayomi masyarakat, tetapi juga harus berpatokan pada hierarki peraturan perundangundangan, salah satunya adalah asas lex generalis derogad lex

18 Zamzam Rizky Faizal Dio. 2015. Kajian Yuridis Partisipasi Masyarakat Dalam Undangundang Nomor 6 Tahun 2014 Tentang Desa. Fakultas Hukum Universitas Brawijaya 
specialis yaitu peraturan bersifat umum dilemahkan oleh peraturan bersifat khusus. Bila ada pertentangan peraturan secara hierarki digunakan asas lex superiori derogad lex inferiori yaitu peraturan yang lebih tinggi melemahkan peraturan yang lebih rendah. Maka dari itu, asas hukum diharapkan bersifat luwes agar tidak terjadi masalah yang berkepanjangan akibat dari pertentangan antara peraturan yang bersifat umum dan khusus. Masyarakat dan aparatur pemerintah diharapkan menyadari bahwa peraturan hukum baik yang bersifat umum maupun khusus dibuat demi menciptakan ketertiban dan kesejahteraan bersama.

Mengacu pada Undang-Undang Nomor 6 Tahun 2014 pasal 7 tersebut pemerintah desa tidak dapat begitu saja membentuk sebuah peraturan desa untuk menjabarkan peraturan perundangundangan lebih tinggi, jika tidak ada perintah dari peraturan perundang-undangan atau pendelegasian karena urusan atau kewenangan asli yang diselenggarakan oleh desa sangat terbatas. Keterbatasan pemerintah desa tersebut dihapus dengan disahkannya Undang-Undang Nomor 6 Tahun 2014. Undang-Undang Nomor 6 Tahun 2014 Tentang Desa memberikan keleluasaan yang lebih kepada pemerintah desa dalam menjalankan otonomi desa. Dalam konsideran undang-undang tersebut disampaikan bahwa desa memiliki hak asal usul dan hak tradisional dalam mengatur dan mengurus kepentingan masyarakat setempat dan berperan mewujudkan cita-cita kemerdekaan. Dalam perjalanan ketatanegaraan Republik Indonesia, desa telah berkembang dalam berbagai bentuk sehingga perlu dilindungi dan diberdayakan agar menjadi kuat, maju, mandiri, dan demokratis sehingga dapat menciptakan landasan yang kuat dalam melaksanakan pemerintahan dan pembangunan menuju masyarakat yang adil, makmur, dan sejahtera. Materi muatan yang secara khusus disebut di dalam Undang-Undang Nomor 6 Tahun 2014 untuk ditetapkan 
dengan peraturan desa adalah pembentukan dusun atau dengan sebutan lain (Pasal 3), susunan organisasi dan tata kerja pemerintah desa (Pasal 12), APBDes (Pasal 61 dan 73) Rencana Pembangunan Jangka Menengah Desa (Pasal 64), Pengelolaan Keuangan Desa (Pasal 76), Pembentukan Badan Usaha Milik Desa (Pasal 78), dan Pembentukan Lembaga Kemasyarakatan (Pasal 89). Proses penyusunan perundang-undangan meliputi berbagai tingkat penyelesaian, seperti tingkat persiapan, penetapan, pelaksanaan, penilaian dan pemaduan kembali produk yang sudah jadi. Seorang perancang peraturan perundangundangan diharuskan mempunyai pengetahuan yang memadai tentang keadaan sosial budaya, sosial ekonomi dan sosial politik masyarakat. Proses penetapan peraturan perundang-undangan memerlukan pengetahuan dan pemahaman yang baik tentang prosedur dan tata cara yang digariskan dalam sistem tata pemerintahan yang berlaku. Fenomena yang terjadi sekarang adalah banyak peraturan perundangan yang tidak sesuai dengan kondisi masyarakat (Huda, 2011:7).

Sesuai dengan Pasal 62 Undang-Undang Nomor 6 Tahun 2014, pembentukkan peraturan desa yang ideal berisi tentang perintah bahwa pedoman pembentukan dan mekanisme penyusunan peraturan desa diatur oleh peraturan daerah kabupaten/kota. Kementerian Dalam Negeri mendukung hal tersebut dengan cara mengeluarkan Peraturan Menteri Dalam Negeri Nomor 29 Tahun 2006 tentang Pedoman Pembentukan dan Mekanisme Penyusunan Peraturan Desa. Akan tetapi pada kenyataannya, pembahasan peraturan desa sering terjadi penyimpangan dalam proses penyusunannya. Pemerintah sebagai organisasi yang menjalankan negara tidak menjalankan fungsinya dengan baik. Hal ini dikarenakan, peraturan pemerintah yang dijadikan acuan oleh masyarakat desa bermasalah. Peraturan desa membutuhkan partisipasi masyarakat dalam pembentukkannya. Hal ini 



\section{BAB V \\ JANGKAUAN, ARAH PENGATURAN, DAN RUANG LINGKUP MATERI MUATAN UNDANG-UNDANG}

\section{A. Sasaran}

Arah pengaturan dari Peraturan Daerah yang akan dibentuk ini adalah memberikan landasan dan kepastian hukum dalam penetapan pedoman teknis penyusunan peraturan desa. Sasaran yang hendak diwujudkan dari Peraturan Daerah yang akan dibentuk ini adalah terwujudnya penyusunan pedoman teknis penyusunan peraturan desa. Dengan demikian penyusunan penyusunan pedoman teknis penyusunan peraturan desa melibat partisipasi masyarakat desa, baik melalui badan permusyawaratan desa, lembaga-lembaga yang ada di desa, maupun partisipasi langsung dengan memberikan masukan lisan dan/atau tertulis.

\section{B. Jangkauan dan Arah Pengaturan}

Jangkauan pengaturan dari Peraturan Daerah yang akan dibentuk ini adalah memberikan pedoman bagi:

a. Pemerintah Kabupaten dalam memfasilitasi dan membimbing pemerintahan desa menetapkan pedoman teknis penyusunan peraturan desa;

b. Pemerintahan Desa dalam menyusun dan menetapkan peraturan desa.

\section{Ruang Lingkup Muatan Materi Undang-Undang}

Ketentuan Umum

Ketentuan umum berisi :

a. Batasan pengertian atau defenisi

b. Singkatan atau akronim yang dituangkan dalam batasan pengertian atau defenisi 
c. Hal-hal lain yang bersifat umum yang berlaku bagi pasal atau beberapa pasal berikutnya antara lain ketentuan yang mencerminkan asas, maksud dan tujuan tanpa dirumuskan tersendiri dalam pasal atau bab.

- Daerah adalah ..................;

- Pemerintah Daerah adalah Bupati dan Perangkat Daerah sebagai unsur penyelenggara Pemerintahan Daerah;

- Bupati adalah Bupati ......;

- Kecamatan adalah wilayah kerja Camat sebagai Perangkat Daerah;

- Camat adalah pimpinan kecamatan sebagai unsur Perangkat Daerah;

- Desa adalah kesatuan masyarakat hukum yang memiliki batas wilayah yang berwenang untuk mengatur dan mengurus urusan pemerintahan, kepentingan masyarakat setempat berdasarkan prakarsa masyarakat, hak asal usul dan/atau hak tradisional yang diakui dan dihormati dalam sistem pemerintahan Negara Kesatuan Republik Indonesia;

- Pemerintahan Desa adalah penyelenggaraan urusan pemerintahan dan kepentingan masyarakat setempat dalam sistem pemerintahan Negara Kesatuan Republik Indonesia;

- Pemerintah Desa adalah Kepala Desa dibantu Perangkat Desa sebagai unsur penyelenggara Pemerintahan Desa;

- Kepala Desa adalah pejabat Pemerintah Desa yang mempunyai wewenang, tugas dan kewajiban untuk menyelenggarakan rumah tangga desanya dan melaksanakan tugas dan Pemerintah dan Pemerintah Daerah;

- Badan Permusyawaratan Desa yang selanjutnya disingkat BPD adalah lembaga yang melaksanakan fungsi 
pemerintahan yang anggotanya merupakan wakil dari penduduk desa berdasarkan keterwakilam wilayah dan ditetapkan secara demokrasi;

- Perangkat Desa adalah pembantu Kepala Desa yang terdiri dari Sekretaris Desa, Kepala Urusan, Kepala Seksi, Kepala Dusun dan Staf;

- Dusun adalah bagian wilayah dalam desa yang merupakan lingkungan kerja kepala desa dan dipimpin oleh seorang kepala dusun;

- Peraturan Desa adalah peraturan perundang - undangan yang ditetapkan oleh kepala desa setelah dibahas dan disepakati bersama BPD;

- Musyawarah Desa adalah musyawarah antara Badan Permusyawaratan Desa, Pemerintah Desa, dan unsur masyarakat yang diselenggarakan oleh Badan Permusyawaratan Desa untuk menyepakati hal yang bersifat strategis;

- Peraturan Bersama Kepala Desa adalah Peraturan yang ditetapkan oleh dua atau lebih Kepala Desa dan bersifat mengatur;

- Peraturan Kepala Desa adalah Peraturan yang ditetapkan oleh Kepala Desa dan bersifat mengatur;

- Keputusan Kepala Desa adalah penetapan yang bersifat konkrit, individual, dan final;

- Evaluasi adalah pengkajian dan penilaian terhadap rancangan Peraturan Desa untuk mengetahui bertentangan dengan kepentingan umum dan/atau Peraturan Perundangundangan yang lebih tinggi;

- Pengundangan adalah penempatan Peraturan di desa dalam Lembaran Desa atau Berita Desa; 
Materi Muatan

1. Ketentuan sanksi

Pengaturan pengawasan produk hukum desa terkait dengan sanksi yang diberikan kepada desa apabila desa tidak melakukan penyusunan Peraturan di desa sebagaimana diperintahkan oleh peraturan perundang-undangan yang berlaku dan siapa yang melaksanakan pengawasan serta mekanisme pengenaan sanksi bagi desa.

Sanksi bagi desa yang tidak menindaklanjuti hasil evaluasi maupun klarifikasi serta jangka waktu setiap tahapan guna kepastian pemberlakuan suatu peraturan di desa.

2. Pelaksanaan

Tata Cara Penyusunan Peraturan di Desa memuat mengenai tahapan penyusunan masing-masing jenis peraturan di desa, diawali dari tahap perencanaan, penyusunan, pembahasan hingga pengundangan.

Penyusunan peraturan di desa, jenis-jenis peraturan di desa dan kewenangan pembentukannya, serta materi pada masingmasing jenis peraturan di desa.

3. Pengawasan

Pengaturan pengawasan produk hukum desa terkait dengan sanksi yang diberikan kepada desa apabila desa tidak melakukan penyusunan Peraturan di desa sebagaimana diperintahkan oleh peraturan perundang-undangan yang berlaku dan siapa yang melaksanakan pengawasan serta mekanisme pengenaan sanksi bagi desa.

4. Evaluasi

Evaluasi Raperdes dan Klarifikasi Peraturan di Desa memuat jenis-jenis peraturan di desa yang diwajibkan evaluasi, mekanisme 
evaluasi rancangan peraturan di desa dan klarifikasi peraturan di desa

5. Pembiayaan

Pembiayaan perlu diatur sehingga perencanaan pembentukan peraturan di desa dapat berjalan lancar.

6. Ketentuan Penutup

Ketentuan Peralihan penting untuk mengatur status suatu peraturan di desa yang sudah ditetapkan atau sedang dalam proses. Penutup yang berisi pemberlakuan peraturan daerah ini. 


\section{।}

\section{BAB VI}

PENUTUP

\section{A. Kesimpulan}

Pengundangan Undang-Undang Nomor 6 Tahun 2014 tentnag Desa berakibat pada perubahan kedudukan Pemerintah Desa menjadi pemerintah yang otonom. Pemerintah Desa yang otonom ini berwenang menyelenggarakan pemerintahannya sendiri, dan tidak sekedar melaksanakan urusan pemerintahan diatasnya di desa. Dengan perubahan paradigma pemerintahan di desa ini, maka pemerintah desa memiliki kewenangan yang luas menyangkut kepentingan desanya. Sehingga indikator kemajuan desa ditentukan oleh masyarakat desa yang bersangkutan melalui musyawarah desa.

Peran hukum dalam pembangunan direduksi menjadi mewujudkan ketertiban dalam masyarakat. Oleh sebab itu, dalam menyelenggarakan pemerintahan di desa, maka dibutuhkan kepastian akan ketertiban hubungan antara lembaga dan masyarakat sehingga penyelenggaraan pembangunan dan berbagai upaya mewujudkan tujuan pembangunan di desa dapat diselenggarakan dalam kepastian hukum. Oleh sebab itu, peran peraturan di desa menjadi penting karenanya proses pembentukan dan substansi pengaturan harus mencerminkan upaya perwujudan ketertiban tersebut.

Pengaturan tentang Peraturan di Desa harus mendasarkan pada ketentuan peraturan perundang-undangan yang lebih tinggi serta berdasarkan atas kaidah hukum umum yang berlaku. Pengaturan tentang Peraturan di Desa.

Oleh sebab itu perlu dirumuskan dengan baik dan melibatkan berbagai elemen masyarakat sehingga diharapkan pengaturan baru nanti dapat diterima dan dilaksanakan dengan baik. 


\section{B. Rekomendasi}

Penyusunan naskah akademik Peraturan Daerah tentang pedoman penyusunan Peraturan Desa merupakan kajian agar produk peraturan Desa yang dikeluarkan Desa betul-betul telah melalui prosedur dan tidak bertentengan dengan peraturan yang lebih tinggi. Untuk itu pemerintah ................. harus segera membentuk tim evaluasi dan klarifikasi Peraturan Desa. Hal ini untuk membantu dan memberikan bimbingan teknis terkait produk peraturan kepada seluruh pemerintah Desa. 


I

\section{LAMPIRAN KONSEP AWAL RANCANGAN UNDANG-UNDANG}

Konsep Awal Undang-Undang yang terdiri dari pasal-pasal yang diusulkan dengan didasarkan pada uraian akademik.

\section{Konsiderans :}

- bahwa dalam rangka penyelenggaraan Pemerintahan Desa, perlu mengatur mengenai keberadaan dan materi muatan peraturan/ produk hukum di desa;

- bahwa dengan telah ditetapkannya Undang - Undang Nomor 6 Tahun 2014 tentang Desa, Peraturan Daerah Nomor 37 Tahun 2007 tentang Pedoman Pembentukan dan Mekanisme Penyusunan peraturan Desa dipandang sudah tidak sesuai dengan ketentuan peraturan perundang - undangan sehingga perlu disesuaikan dan disempurnakan;

- bahwa berdasarkan pertimbangan dimaksud dalam huruf a dan huruf $b$ diatas perlu menetapkan Peraturan daerah tentang Pedoman Teknis Penyusunan Peraturan di Desa.

Dasar Hukum :

- Undang-Undang Republik Indonesia Nomor 33 Tahun 2004 tentang Perimbangan Keuangan antara Pemerintah Pusat dan Pemerintah 
Daerah ( Lembaran Negara Republik Indonesia Tahun 2004 Nomor 126, Tambahan Lembaran Negara Republik Indonesia Nomor 4438 );

- Undang-Undang Republik Indonesia Nomor 12 Tahun 2011 tentang Pembentukan Peraturan Perundang-Undangan ( Lembaran Negara Republik Indonesia Tahun 2011 Nomor 82, Tambahan Lembaran Negara Republik Indonesia Nomor 5234 );

- Undang-Undang Republik Indonesia Nomor 6 Tahun 2014 tentang Desa ( Lembaran Negara Republik Indonesia Tahun 2014 Nomor 7, Tambahan Lembaran Negaea Republik Indonesia Nomor 5495 );

- Undang-Undang Nomor 23 Tahun 2014 tentang Pemerintah Daerah (Lembaran Negara Republik Indonesia Tahun 2014 Nomor 244, Tambahan Lembaran Negara Republik Indonesia Nomor 5587); sebagaimana telah beberapa kali diubah terakhir dengan UndangUndang Nomor 9 Tahun 2015 tentang Perubahan Kedua Atas UndangUndang Nomor 23 Tahun 2014 tentang Pemerintahan Daerah ( Lembaran Negara Republik Indonesia Tahun 2015 Nomor 58, Tambahan Lembaran Negara Republik Indonesia Nomor 5679 );

- Peraturan Pemerintah Nomor 43 Tahun 2014 tentang Petunjuk Pelaksanaan Undang-Undang Nomor 6 Tahun 2014 tentang Desa (Lembaran Negara Republik Indonesia Tahun 2014 Nomor 123, Tambahan Lembaran Negara Republik Indonesia Nomor 5539) sebagaimana telah diubah dengan Peraturan Pemerintah Nomor 47 Tahun 2015 tentang Perubahan Atas Peraturan Pemerintah Nomor 43 Tahun 2014 tentang Peraturan Pelaksanaan Undang-Undang Nomor 6 Tahun 2014 tentang Desa (Lembaran Negara Republik Indonesia Tahun 2015 Nomor157, Tambahan Lembaran Negara Republik Indonesia Nomor 5717);

- Peraturan Menteri Dalam Negeri Republik Indonesia Nomor 111 tahun 2014 tentang Pedoman teknis Peraturan di Desa (Berita Negara Republik Indonesia Tahun 2014 Nomor 2091). 
Ketentuan Umum :

- Daerah adalah ...................;

- Pemerintah Daerah adalah Bupati dan Perangkat Daerah sebagai unsur penyelenggara Pemerintahan Daerah;

- Bupati adalah Bupati ......;

- Kecamatan adalah wilayah kerja Camat sebagai Perangkat Daerah;

- Camat adalah pimpinan kecamatan sebagai unsur Perangkat Daerah;

- Desa adalah kesatuan masyarakat hukum yang memiliki batas wilayah yang berwenang untuk mengatur dan mengurus urusan pemerintahan, kepentingan masyarakat setempat berdasarkan prakarsa masyarakat, hak asal usul dan/atau hak tradisional yang diakui dan dihormati dalam sistem pemerintahan Negara Kesatuan Republik Indonesia;

- Pemerintahan Desa adalah penyelenggaraan urusan pemerintahan dan kepentingan masyarakat setempat dalam sistem pemerintahan Negara Kesatuan Republik Indonesia;

- Pemerintah Desa adalah Kepala Desa dibantu Perangkat Desa sebagai unsur penyelenggara Pemerintahan Desa;

- Kepala Desa adalah pejabat Pemerintah Desa yang mempunyai wewenang, tugas dan kewajiban untuk menyelenggarakan rumah tangga desanya dan melaksanakan tugas dan Pemerintah dan Pemerintah Daerah;

- Badan Permusyawaratan Desa yang selanjutnya disingkat BPD adalah lembaga yang melaksanakan fungsi pemerintahan yang anggotanya merupakan wakil dari penduduk desa berdasarkan keterwakilam wilayah dan ditetapkan secara demokrasi; 
- Peraturan Desa adalah peraturan perundang - undangan yang ditetapkan oleh kepala desa setelah dibahas dan disepakati bersama BPD;

- Peraturan Bersama Kepala Desa adalah peraturan yang ditetapkan oleh dua atau lebih Kepala Desa dan bersifat mengatur;

- Peraturan BPD adalah peratiran yang ditetapkan oleh BPD dan bersifat mengatur;

- Peraturan Kepala Desa adalah peraturan yang ditetapkan oleh Kepala Desa dan bersifat mengatur;

- Keputusan Kepala Desa adalah penetapan yang bersifat konkrit, individual dan final;

- $\quad$ Keputusan BPD adalah keputusan yang ditetapkan oleh BPD;

- Evaluasi adalah pengkajian dan penilaian terhadap rancangan Peraturan Desa untuk mengetahui bertentangan dengan kepentingan umum dan/atau peraturan perundang-undangan yang lebih tinggi;

- Pengundangan adalah penempatan peraturan di desa dalam Lembaran Desa atau Berita Desa;

- Klarifikasi adalah pengkajian dan penilaian terhadap peraturan di desa untuk mengetahui bertentangan dengan kepentingan umum, dan/atau peraturan perundang-undangan yang lebih tinggi;

- Bertentangan dengan kepentingan umum adalah kebijakan yang menyebabkan terganggunya kerukunan antar warga masyarakat, terganggunya akses terhadap pelayanan publik, terganggunya ketentraman dan ketertiban umum, terganggunya kegiatan ekonomi untuk meningkatkan kesejahteraan masyarakat dan/atau diskriminasi terhadap suku, agama dan kepercayaan, ras antar golongan dan gender;

- Anggaran Pendapatan dan Belanja Desa yang selanjutnya disingkat APB Desa adalah rencana keuangan tahunan pemerintahan desa. 


|

\section{Materi :}

Maksud, Tujuan Dan Sasaran

Maksud disusunnya Peraturan Daerah ini adalah sebagai Pedoman bagi Pemerintah Desa dan BPD dalam menyusun peraturan di desa.

Tujuan khusus

Tujuan disusunnya Peraturan Daerah ini agar dalam pembentukan peraturan di desa sesuai dengan asas pembentukan peraturan perundang-undangan dan sesuai dengan materi muatan peraturan di desa.

Tujuan umum

Untuk memberikan kepastian hukum terkait dengan pedoman teknis penyusunan peraturan desa.

Sasaran

Sasaran dalam Peraturan Daerah pedoman teknis penyusunan peraturan Desa adalah seluruh masyarakat yang berdomisili diwilayah

Penilaian

Untuk menilai suatu rancangan peraturan desa diperlukan evaluasi dan klarifikasi yang dilakukan oleh Bupati dalam hal ini didelegasikan kepada Camat. Bupati juga dapat membentuk tim evaluasi rancangan Peraturan desa yang ditetapkan melalui keputusan Bupati. 
Pelaksana

Ruang lingkup Peraturan Desa meliputi ;

a. Peraturan-peraturan Desa yang terdiri dari

- Peraturan Desa

- Peraturan Bersama Kepala Desa

- Peraturan Kepala Desa

- Keputusan Kepala Desa

b. Peraturan Peraturan BPD yang terdiri dari

- Peraturan BPD

- Keputusan BPD

- Keputusan Pimpina BPD

Pembentukan suatu peraturan Desa dilakukan beberapa tahapan, yaitu 1. Perencanaan

penyusunan Rancangan Peraturan Desa ditetapkan oleh Kepala Desa dan BPD dalam Rencana Kerja Pemerintah Desa.

Lembaga Kemasyarakatan dan Lembaga Desa lainnya di desa dapat memberikan masukan kepada Pemerintah Desa dan/atau BPD untuk rencana penyusunan Rancangan Peraturan Desa.

2. Penyusunan

Penyusunan Rancangan Peraturan Desa diprakarsai oleh Pemerintah Desa.

Rancangan Peraturan Desa yang telah disusun, disosialisasikan kepada masyarakat desa dan dapat dikonsultasikan kepada Camat untuk mendapat masukan.

Rancangan Peraturan Desa yang disosialisasikan diutamakan kepada masyarakat atau kelompok masyarakat yang terkait langsung dengan substansi materi pengaturan.

Masukan dari masyarakat desa dan Camat digunakan Pemerintah Desa untuk tindak lanjut proses penyusunan Rancangan Peraturan Desa. 
Rancangan Peraturan Desa yang telah disosialisasikan sebagaimana dimaksud pada ayat (3) disampaikan Kepala Desa kepada BPD untuk dibahas dan disepakati bersama.

Penyusunan Peraturan Desa Oleh BPD

BPD dapat mengusulkan dan menyusun Peraturan Desa selain dalam hal:

- Rancangan Peraturan Desa tentang Rencana Pembangunan Jangka Menengah Desa;

- Rancangan Peraturan Desa tentang Rencana Kerja Pemerintah Desa;

- Rancangan Peraturan Desa tentang APB Desa; dan

- Rancangan Peraturan Desa tentang Pertanggungjawaban Realisasi Pelaksanaan APB Desa.

3. Pembahasan

- Rancangan Peraturan Desa yang disusun oleh Kepala Desa disampaikan kepada BPD dengan Surat Pengantar untuk dapat dibahas.

- BPD mengundang Kepala Desa untuk membahas dan menyepakati Rancangan Peraturan Desa.

- Dalam hal terdapat Rancangan Peraturan Desa prakarsa Pemerintah Desa dan usulan BPD mengenai hal sama untuk dibahas dalam waktu pembahasan yang sama, maka didahulukan Rancangan Peraturan Desa usulan BPD sedangkan rancangan Peraturan Desa usulan Kepala Desa digunakan sebagai bahan untuk dipersandingkan.

- Dalam jangka waktu paling lama 7 (tujuh) hari sejak diteroimanya Rancangan Peraturan Desa oleh BPD, maka BPD harus sudah membahas Rancangan Peraturan Desa.

- Ketentuan Lebih lanjut mengenai tata cara pembahasan Rancangan Peraturan Desa oleh BPD dapat diatur dalam Peraturan BPD tentang Tata Tertib BPD. 


\section{Penetapan}

- Rancangan peraturan Desa yang telah disepakati bersama disampaikan oleh pimpinan BPD kepada Kepala Desa untuk ditetapkan menjadi Peraturan Desa paling lambat 7 (tujuh) hari terhitung sejak tanggal kesepakatan.

- Dikecualikan dari ketentuan terhadap Rancangan Peraturan Desa yang dilakukan mekanisme evaluasi yaitu Rancangan Peraturan Desa tentang :
a. APB Desa;
b. Pungutan Desa;
c. Tata Ruang Desa;
d. Susunan Organisasi dan Tata Kerja Pemerintah Desa.

- Rancangan Peraturan Desa wajib ditetapkan oleh Kepala Desa dengan membubuhkan tanda tangan paling lambat 15 (lima belas) hari terhitung sejak diterimanya Rancangan Peraturan Desa dari Pimpinan BPD.

- Dalam hal Rancangan Peraturan Desa tidak ditandatangani oleh Kepala Desa dalam waktu opaling lama 15 (lima belas) hari sejak diterimanya Rancangan Peraturan Desa tersebut sah menjadi Peraturan Desa dan wajib diundangkan.

- Dalam hal sahnya Rancangan Peraturan Desa sebagaimana dimaksud diatas, maka kalimat pengesahannya berbunyi: Peraturan Desa ini dinyatakan sah.

- Kalimat pengesahan yang berbunyi Peraturan Desa ini dinyatakan sah dibubuhkan tantangan oleh Sekretaris Desa pada halaman terakhir Peraturan Desa sebelum pengundangan naskah Peraturan Desa ke dalam Lembaran Desa. 
5. Pengundangan

- Sekretaris Desa mengundangkan Peraturan Desa dalam Lembaran Desa.

- Peraturan Desa mencantumkan batas waktu penetapan pelaksanaan.

- Peraturan Desa dinyatakan mulai berlaku dan mempunyai kekuatan hukum yang mengikat sejak diundangkan.

6. Penyebarluasan

- Penyebarluasan dilakukan oleh Pemerintah Desa dan BPD sejak tahapan :

a. Penetapan Rencana Penyusunan Rancangan Peraturan Desa;

b. Penyusunan Rancangan Peraturan Desa;

C. Pembahasan Rancangan Peraturan Desa; dan

d. Pengundangan Peraturan Desa.

- Penyebarluasan sebagaimana dimaksud pada huruf $a$, huruf b dan huruf c dilakukan untuk memberikan informasi dan memperoleh masukan masyarakat dan para pemangku kepentingan.

- Penyebarlauasan sebagaimana dimaksud pada huruf d dimaksudkan untuk memberikan sosialisasi dan pemahaman terhadap Peraturan Desa.

Pembiayaan

Pembiayaan pembentukan Peraturan di Desa dibebankan pada Anggaran Pendapatan dan Belanja Desa.

\section{Sanksi}

Ketentuan sanksi bagi desa yang tidak mengikuti pedoman teknis penyusunan Peraturan desa akan diberikan sanksi pembinaan dan sanksi administratif. 


\section{Referensi:}

Peraturan Menteri Dalam Negeri Nomor 111 Tahun 2014 tentang Pedoman Tehnis Penyusunan Peraturan di Desa

Peraturan Pemerintah Republik Indonesia Nomor 43 Tahun 2014 Tentang Peraturan Pelaksanaan Undang-Undang Nomor 6 Tahun 2014 Tentang Desa.

Umanailo, M Chairul Basrun. 2018. proses modernisasi dan pergeseran okupasi. researchgate.net/publication/323935634_proses_modernisasi_dan_per geseran_okupasi. DOI: 10.13140/RG.2.2.19671.78241.

Umanailo, M. C B. 2017. "MASYARAKAT BURU DALAM PERSPEKTIF KONTEMPORER." Open Science Framework. December 10. doi:10.17605/OSF.IO/KZGX3

Umanailo, M. C. B. (2017, December 11). KAJIAN DAN ANALISIS SOSIOLOGI. http://doi.org/10.17605/OSF.IO/PV24F.

Umanailo, M. C. B. (2017, December 11). SOSIOLOGI HUKUM. http://doi.org/10.17605/OSF.IO/KHFNU

Umanailo, M. C. B. (2018, March 17). Ilmu Sosial Budaya Dasar. http://doi.org/10.17605/OSF.IO/4HPWC.

Undang-Undang Dasar 1945

Undang-Undang Republik Indonesia Nomor 12 Tahun 2011 Tentang Pembentukan Peraturan Perundang-Undangan

Undang-Undang Republik Indonesia Nomor 23 Tahun 2014 Tentang Pemerintahan Daerah

Undang-Undang Republik Indonesia Nomor 6 Tahun 2014 Tentang Desa 